\title{
Ethics, Morality, and Disruption of U.S. Immigration Laws
}

\author{
Bill Ong Hing*
}

\section{INTRODUCTION}

Immigrants and immigrant rights advocates knew we were in trouble when a $\mathrm{Ku}$ Klux Klan "knight" called for shooting unaccompanied children (UACs) arriving at the border ${ }^{1}$ and the Obama administration expedited removal proceedings of UACs and children arriving at the border with other family members. ${ }^{2}$ Indeed, the Loyal White Knights of the Klan advocate a "shoot-to-kill" border policy," and one North Carolina Klan leader said the policy should apply to UACs: "If we pop a couple of 'em off and leave the corpses laying on the border, maybe they'll see we're serious about stopping immigrants." Although the White House initially labeled the influx of UACs an "urgent humanitarian situation,"5 the Department of Homeland Security (DHS) and Department of Justice responded by sending a "surge" of immigration judges and government attorneys to the border to start deportation hearings immediately, while simultaneously sending the message to immigration courts around the country that UAC-related cases should be prioritized. ${ }^{6}$

\footnotetext{
* Professor of Law, University of San Francisco, Professor of Law Emeritus, University of California, Davis. Thank you to Amelia Andersen for her able research assistance.

1. Leslie Savan, The KKK Wants a 'Shoot to Kill' Policy to Include Migrant Children, THE NATION (July 30, 2014, 3:53 PM), http://www.thenation.com/blog/180840/kkk-wants-shoot-killpolicy-aimed-immigrant-children\#.

2. Katie Zezima, White House: 'Most' Unaccompanied Minors at Border Will Likely Be Deported, WASHINGTON POST (July 7, 3014), http://www.washingtonpost.com/blogs/post-politics/ wp/2014/07/07/white-house-most-unaccompanied-minors-at-border-will-likely-be-deported/.

3. Savan, supra note 1.

4. Id.

5. Katie Zezima \& Ed O'Keefe, Obama Calls Wave of Children Across U.S.-Mexican Border 'Urgent Humanitarian Situation,' WASHINGTON POST (June 2, 2014), http://www.washing tonpost.com/politics/obama-calls-wave-of-children-across-us-mexican-border-urgent-humanitariansituation/2014/06/02/4d29df5e-ea8f-11e3-93d2-edd4be1f5d9e_story.html.

6. See Alan Gomez, Obama Orders 'Surge' to Border to Speed Up Deportations, USA ToDAY (June 20, 2014), http://www.usatoday.com/story/news/nation/2014/06/20/obama-immigration-
} 
Time and again, the enforcement of U.S. immigration laws over the past twenty years should make us wonder about the cost we are willing to pay to enforce the nation's immigration laws. Not simply in terms of the billions of dollars spent on enforcement, ${ }^{7}$ but also the cost in terms of our basic humanity. In the name of border integrity and uninformed economic claims, hundreds of migrants die each year attempting to cross our southern border due to the expanded militarization of the border that began with Operation Gatekeeper. ${ }^{8}$ Hardworking immigrants were victimized by Bush-era Immigration and Customs Enforcement (ICE) raids, ${ }^{9}$ and thousands more lose their jobs each year because of the Obama administration's silent raids. ${ }^{10}$ The current administration also has begun taking a page from the Bush era, instituting raids of workplaces frequented by Latinos in New Orleans and other parts of the country. ${ }^{11}$ The result is family separation - often involving U.S. citizen members. ${ }^{12}$ Such destruction to families also results from the expansion of the so-called Secure Communities program under the Obama administration's watch, as well as the deportation of refugees and longtime lawful permanent residents convicted of aggravated feloniesin spite of an acknowledgement in criminal justice communities that engaging in rehabilitation efforts would be wiser. ${ }^{13}$ Obama's DHS also made credible fear standards for refugees fleeing to our borders more rigorous, then more inhumanely called for expeditious removal of the thousands of unaccompanied children arriving at our border who are fleeing violence. ${ }^{14}$

unaccompanied-minors-deportations/11070531/; see also Kate Linthicum, 7,000 Immigrant Children Ordered Deported Without Going to Court, L.A. Times (Mar. 6, 2015), http://www.latimes.com/local/california/la-me-children-deported-20150306-story.html\#page=1;

Richard Gonzales, Immigration Courts 'Operating In Crisis Mode,' Judges Say, NPR (Feb. 23,

2015), http://www.npr.org/2015/02/23/387825094/immigration-courts-operating-in-crisis-modejudges-say.

7. See Louis Jacobson, Luis Gutierrez Says U.S. Spends More on Immigration Enforcement Than Other Agencies Combined, POLitifact.com (July 15, 2014, 1:56 PM), http://www.politifact.com/truth-o-meter/statements/2014/jul/15/luis-gutierrez/luis-gutierrez-says-usspends-more-immigration-bor/ ("We spent $\$ 18$ billion a year on making sure that the federal government has immigrant enforcement agents").

8. Jill Holslin, Operation Gatekeeper: 20 Years of Militarizing the Border, ATTHEEDGES.COM (Oct. 1, 2014, 9:27 AM), http://www.attheedges.com/2014/10/01/operation-gatekeeper-20-years-ofmilitarizing-the-border/.

9. See infra notes $20-21$ and accompanying text.

10. See infra notes 29-34 and accompanying text.

11. See infra note 35 and accompanying text.

12. Id.

13. See infra notes $22-28$ and accompanying text.

14. See infra notes 78-109 and accompanying text. 
In this essay, I review these enforcement tools and what I feel is the unnecessary havoc that they wreak on immigrant communities. In the process, I describe the resistance to these policies by immigrants and their supporters who have attempted to disrupt the enforcement tools. Immigrants and their supporters are attempting to raise awareness of better strategies to resolve whatever problems are perceived to exist. I also argue that the disruptive tactics by immigrants and their supporters have actually helped to push the Obama administration into engaging in disruptive innovation of its own with respect to how to approach certain classes of removable immigrants.

Administrations and officials who engage in these enforcement approaches need to be held accountable to fair-minded, humanisticthinking Americans. These actions have occurred on our watch, and we should not stand by idly. Thus, I also submit that we should devise methods of holding officials accountable, perhaps by creating a public oversight group along the lines of citizen oversight panels of police departments that would focus on the anti-humanitarian effects of immigration enforcement.

\section{NightMARISH ICE ENFORCEMENT TOOLS}

Over the past twenty years, the Immigration and Naturalization Service (INS) or, after 9/11, Immigration and Customs Enforcement (ICE) has engaged in immigration enforcement actions that, in my view, go far beyond what is necessary under the law. These efforts have crossed the line between what is necessary to enforce the immigration laws and over-zealous tools that wreak unnecessary havoc on communities and a common sense of humanity and decency. In this part of the article, I summarize a handful of ICE and INS enforcement tools and priorities that should raise the eyebrows of decent-minded observers.

\section{A. Operation Gatekeeper}

Beginning in 1994, the Clinton administration implemented Operation Gatekeeper, a strategy of "prevention through deterrence" that involved constructing fences and militarizing parts of the southern border that were most easily traversed. ${ }^{15}$ Instead of deterring migrants, their entry choices were shifted to treacherous terrain - the desert and the

15. Material accompanying footnotes 15 through 16 is Author's analysis of Operation Gatekeeper as previously published in Bill Ong Hing, Defining America Through IMmigration POLICY 185-88 (2004). 
mountains. The number of entries and apprehensions were not at all decreased, and the number of deaths because of dehydration and sunstroke in the summer or freezing in the winter dramatically surged. In 1994, fewer than thirty migrants died along the border; by 1998, the number was 147; in 2001, 387 deaths were counted; and in 2007, 409 died.

The San Diego Sector of the DHS Border Patrol covers the section of the United States-Mexico border that historically has been the preferred site of entry for those entering the United States without inspection. This sector contains sixty-six miles of international border. Tijuana, Mexico's third largest city, lies directly south of San Diego, California, the sixth largest city in the United States. A smaller Mexican city, Tecate, is situated in the eastern end of the sector.

In 1994, over 450,000 apprehensions of illicit border crossings were made in the San Diego sector. This number far surpassed the sectors with the next highest apprehension: Tucson $(139,473)$ and McAllen, Texas $(124,251)$. In the period prior to the end of 1994, undocumented border crossers in the San Diego sector commonly entered in the western part of the sector near the city of San Diego. Often, many of these individuals traveled through private property, and some were even seen darting across busy freeways near the international border inspection station. Clearly, most of the illicit crossers entered along the fourteenmile area from Imperial Beach (at the Pacific Ocean) to the base of the Otay Mountains. Most of the stretch involves "easy terrain and gentle climbs," where the crossing lasts only ten or fifteen minutes to a pickup point. Even individuals who were apprehended and turned back across the border were just as likely to attempt reentry in the westernmost part of the sector at that time.

These highly visible border crossings resulted in tremendous public pressure on the INS to act. Residents of San Diego complained. Antiimmigrant groups demanded action. Politicians decried lack of border control. President Clinton came up with an answer and an approach to the question of "illegal immigration." In his State of the Union address on January 24, 1995, Clinton signaled a renewed get-tough policy against undocumenteds, including "mov[ing] aggressively to secure our borders by hiring a record number of border guards" and "cracking down on illegal hiring." Knowing that Clinton faced reelection in 1996, administration officials hoped that renewed enforcement effort against undocumented aliens would shore up the president's support among voters in California, who overwhelmingly passed the anti-immigrant Proposition 187 in 1994. 
Operation Gatekeeper was one of several operations that resulted from the Clinton administration's commitment to a new aggressive enforcement strategy for the Border Patrol. In August 1994, the INS Commissioner Doris Meissner approved a new national strategy for the Border Patrol. The heart of the plan relied on a vision of "prevention through deterrence," in which a "decisive number of enforcement resources [would be brought] to bear in each major entry corridor" and the Border Patrol would "increase the number of agents on the line and make effective use of technology, raising the risk of apprehension high enough to be an effective deterrent." The specific regional enforcement operations that resulted included (1) Operation Blockade (later renamed Hold the Line), which commenced in September 1993 in the Greater El Paso, Texas areas; (2) Operation Gatekeeper, which commenced in October 1994, south of San Diego, California; (3) Operation Safeguard, which also commenced in October 1994 in Arizona; and (4) Operation Rio Grande, which commenced in August 1997 in Brownsville, Texas. The idea was to block traditional entry and smuggling routes with border enforcement personnel and physical barriers. By cutting off traditional crossing routes, the strategy sought to deter migrants or at least channel them into terrain less suited for crossing and more conducive to apprehensions. To carry out the strategy, the Border Patrol was to concentrate personnel and resources in areas of highest undocumented alien crossings, increase the time agents spent on border-control activities, increase use of physical barriers, and carefully consider the mix of technology and personnel needed to control the border.

In the San Diego sector, efforts would be concentrated on the popular fourteen-mile section of the border beginning from the Pacific Ocean (Imperial Beach) stretching eastward. That stretch had been the focus of some resources before Gatekeeper. Steel fencing and bright lighting were already in place in sections of this corridor, erected in part with the assistance of the U.S. military. Yet because of the persistent traffic of undocumented entrants along this corridor, phase I of Gatekeeper continued to concentrate on increased staffing and resources along the fourteen mile area.

As the INS implemented its national border strategy, Congress supported these efforts; between 1993 and 1997, the INS budget for enforcement efforts along the southwest border doubled from $\$ 400$ million to $\$ 800$ million. The number of Border Patrol agents along the southwest border increased from 3,389 in October 1993 to 7,357 by September 1998 - an increase of 117 percent. State-of-the-art technology, including new surveillance systems using electronic sensors linked with low-light video cameras, infrared night-vision devices, and 
forward-looking infrared systems for Border Patrol aircraft, were installed.

Given these additional resources, Operation Gatekeeper buildup was impressive. Before Gatekeeper, the San Diego sector had nineteen miles of fencing. By the end of 1999, fifty-two miles were fenced. Half of this fencing runs from the Pacific Ocean to the base of the Otay Mountains. Fourteen miles contain primary fencing (a ten-foot wall of corrugated steel landing mats left over from the Vietnam War). Two backup fences, each 115 feet tall, have been constructed. The first backup fence is made of concrete pillars. The second backup fence is made of wire mesh, with support beams. Both are topped with wire. Almost twelve miles of this stretch are illuminated by stadium lights. Some fencing has been erected on sections of the Otay Mountains, as well as around various East San Diego communities along the border. The Department of Defense's Center for Low Intensity Conflicts as well as the Army Corps of Engineers provided guidance to INS on the development of Gatekeeper features.

In contrast, in areas other than San Diego, the construction was not as significant. The El Centro sector covers seventy-two miles of the border and is sparsely populated on the U.S. side and has only seven miles of fence - all of it between the contiguous border cities of Calexico and Mexicali. Arizona has seventeen miles of fencing - six in the Yuma sector and nine in the Tucson sector. That fencing was erected exclusively in the towns and cities. Texas has the Rio Grande River and seven miles of fencing from El Paso/Ciudad Juarez area-two miles of primary and five of secondary. Thus, seventy-three miles of fencing were erected on the 2,000 mile southwest border and the sixty-six mile San Diego sector contained seventy-two percent of it, as well as fiftyfour percent of the illumination. The 144-mile long San Diego and El Centro sectors have almost a third of the Border Patrol agents stationed on the 2,000 miles of southwest border.

In implementing its national strategy beginning in 1994, the INS made a key assumption about its "prevention through deterrence" approach: "alien apprehensions will decrease as [the] Border Patrol increases control of the border." In other words, the INS anticipated that as the show of force escalated by increasing agents, lighting, and fencing, people would be discouraged from entering without inspection so that the number of apprehensions naturally would decline. In fact, the Border Patrol predicted that within five years, a substantial drop in apprehension rates border-wide would result. The deterrence would be so great that "many will consider it futile to continue to attempt illegal entry." These assumptions and predictions have not borne out. 
Apprehension levels did not decline. The enforcement strategies began with Operation Gatekeeper in San Diego and Operation Blockade in El Paso in 1994. True, apprehension levels for those two sectors were considerably lower in 1998 than in 1993 (e.g., 531,689 apprehended in San Diego in 1993 compared to 248,092 in 1998). However, the apprehension levels surged in El Centro, Yuma, and Tucson during the same period (e.g., from 92,639 to 387,406 in Tucson; from 30,508 to 226,695 in El Centro; and from 23,548 to 76,195 in Yuma). From 1994 to 1999 , total apprehensions statistics along the southwest border actually increased by 57 percent. The increase continues. The number of apprehensions for all of the fiscal year 2000 was 1.64 million, which was an all-time high. In sum, after Gatekeeper sealed the westernmost section of the border, apprehensions in San Diego declined, but crossers moved east and overall apprehensions actually increased substantially.

The INS thought that with the combination of fencing and increased spending on border patrols at the most frequently traveled routes, undocumented immigration would slow if not come to a complete halt altogether. But migrants were not deterred, and began looking for other areas to penetrate the border. However, the new areas of travel were risky; they were more dangerous and life threatening. Given the challenges, more migrants turned to costly smugglers to help them cross the border.

As Operation Gatekeeper closed the Imperial Beach corridor, the border-crossing traffic moved east. Frustrated crossers moved first to Brown Field and Chula Vista, and subsequently to the eastern sections of the San Diego sector. Before Gatekeeper began in 1994, crossers were just as likely to make their second try at the westernmost part of the sector, but that changed very quickly. By January 1995, only fourteen percent were making their second try near Imperial Beach. The illicit border traffic had moved into "unfamiliar and unattractive territory." The tragedy of Operation Gatekeeper is the direct link of its prevention through deterrence strategy to an absolutely horrendous rise in the number of deaths among border-crossers who were forced to attempt entry over terrain that even the INS knew to present "mortal danger" due to extreme weather conditions and rugged terrain.

The death statistics are revealing. In 1994, twenty-three migrants died along the California-Mexico border. Of the twenty-three, two died of hypothermia or heat stroke and nine from drowning. By 1998, the annual total was 147 deaths - seventy-one from hypothermia or heat stroke and fifty-two from drowning. Figures for 1999 follow this unfortunate trend, and in 2000, eighty-four were heat stroke or hypothermia casualties. In spite of the aid of smugglers, the new routes 
were simply too dangerous for many border-crossers and death of migrants surged. The number of migrant deaths increased 600 times from 1994 to 2000; a number that could be attributed to Operation Gatekeeper's pushing surreptitious entries toward treacherous eastward routes. ${ }^{16}$

From 1997 to 2013, over 6,000 known migrant deaths occurred along the Mexico-Arizona border. ${ }^{17}$ The remains of 477 people were found in 2012 alone. $^{18}$ Many more bodies likely remain undiscovered, and of the ones that are found, many go unidentified. ${ }^{19}$

\section{B. Bush ICE Raids}

On a cold, raw December morning in Marshalltown, Iowa, Teresa Blanco woke up to go to work at the local Swift meat packing plant. ${ }^{20}$ Hundreds of others across the town were doing the same thing, in spite of the miserable mixture of sleet, mist, and slush that awaited them outside their front doors. As they made their way to the plant, the workers, who were from Mexico, did not mind the weather.

Unfortunately, the workers' day turned into a nightmare soon after they reported for work. Not long after the plant opened, heavily armed agents from the U.S. Immigration and Customs Enforcement agency stormed onto the scene. Pandemonium broke out. The workers panicked; many began to run; others tried to hide, some in dangerous and hazardous areas. As the ICE agents began rounding up all the workers, they ordered those who were U.S. citizens to go to the cafeteria. Noncitizens were directed to a different section of the plant. Agents shouted out instructions: documenteds in one line, undocumenteds in another. If an agent suspected that the person in the citizens' line was undocumented, the agent would instruct the person to get into the undocumented line. More than one individual was told, "You have

\footnotetext{
16. Id.

17. See Daniel E. Martinez et al., Structural Violence and Migrant Deaths in Southern Arizona: Data from the Pima County Office of the Medical Examiner, 1990-2013, J. ON MigRATION AND HUMAN SECURITY 257, $258 \quad$ (2014), http://www.academia.edu/8980501/Structural_Vi olence_and_Migrant_Deaths_in_Southern_Arizona_Data_from_the_Pima_County_Office_of the Medical_Examiner_1990-2013.

18. Gomez, supra note 6.

19. Patrick O'Driscoll \& Haya El Nasser, Summer Can Be Lethal for Illegals, USA TODAY (May 18, 2003, 11:22 PM), http://usatoday30.usatoday.com/news/nation/2003-05-18-borderusat_x.htm.

20. Material accompanying footnotes 20 through 21 is Author's analysis of the Bush ICE raids as previously published in Bill Ong Hing, Institutional Racism, ICE Raids, and Immigration Reform, 44 USF L.REV. 307, 307 (2009).
} 
Mexican teeth. You need to go to that line [for undocumented persons] and get checked."

The nightmare was only beginning. Although supervisory ICE agents carried a civil warrant for a few individuals, the squad demanded that all plant employees be held, separated by nationality. That included U.S. citizen workers who were interrogated and detained. No one was free to leave-not even those who carried evidence of lawful status or proof they were in the process of seeking proper permission to be in this country. Each was interrogated individually. The process took the entire day, and phone calls were not permitted until later in the day. By the end of the day, ninety were arrested, but hundreds, including citizens, had been detained for hours. The entire community was shaken to its core.

That morning of December 12, 2006, the feast day of Our Lady of Guadalupe and a holy day of special significance to Catholics of Mexican descent, ICE conducted a massive military style raid on six Swift \& Company meatpacking plants across the nation's heartland. Hundreds of federal agents in riot gear, armed with assault weapons, descended upon plants in Cactus, Texas; Greeley, Colorado; Grand Island, Nebraska; Worthington, Minnesota; Marshalltown, Iowa; and Hyrum, Utah.

ICE was there to execute arrest warrants for a handful of named workers - less than one percent of the workforce. The sheer number of ICE agents on the scene and the manner in which the operation was conducted made clear that the execution of those warrants was not the government's real purpose. Rather, the raids seemed designed to ramp up the number of arrests and capture the headlines on the evening news. ICE rounded up nearly 13,000 workers - the vast majority of them U.S. citizens - holding them against their will for hours.

U.S. citizen Melissa Broekemeier worked at the Swift plant in Marshalltown for more than eight years. But the "longest day [she] ever worked was on December 12, 2007." Broekemeier described her experience on the day of the Swift raid this way:

I, like all my coworkers that went to work that day... we were instructed by our supervisors to finish up .... and report to the cafeteria, where we were inspected, and our private lives were scrutinized by ICE agents as if we were illegal convicts.

The power that runs our machines should have been shut off first, but it was not. 
The Federal government jeopardized our safety and health without care. We were overlooked. We were ignored. We were treated like criminals. We were not free to leave.

A different ICE raid in Stillmore, Georgia, the Friday before Labor Day weekend in 2006, evoked outcry from local residents who labeled the ICE action as nothing short of "Gestapo tactics." Descending shortly before midnight, ICE agents swarmed the area, eventually arresting and deporting 125 undocumented workers. Most of those rounded up were men, while their wives fled to the woods to hide children in tow. In the weeks after the raid, at least 200 more immigrants left town. Many of the women purchased bus tickets to Mexico with their husband's final paycheck. The impact underscored how vital undocumented immigrants were to the local economy. Trailer parks lie abandoned. The poultry plant scrambled to replace more than half its workforce. Business dried up at stores. The community of about a thousand people became little more than a ghost town. The operator of a trailer park that was raided, David Robinson, commented, "These people might not have American rights, but they've damn sure got human rights. There ain't no reason to treat them like animals."

Local residents witnessed the events, as ICE officials raided local homes and trailer parks, forcing many members of the community out of Stillmore. Officials were seen stopping motorists, breaking into homes, and there were even reports of officials threatening people with tear gas. Witnesses reported seeing ICE officials breaking windows and entering homes through floorboards. Mayor Marilyn Slater commented, "This reminds me of what I read about Nazi Germany, the Gestapo coming in and yanking people up." ${ }^{21}$

\section{Secure Communities}

The Secure Communities initiative that referred fingerprint information to DHS via the FBI for all participating jurisdictions was intended to focus on serious criminals. ${ }^{22}$ Yet, the vast majority of individuals removed as a result of Secure Communities referrals were

21. Id.

22. Aarti Kohli et al., Secure Communities by the Numbers: An Analysis of Demographics and Due Process 1 The Chief Just. EArl Warren Inst. on L. \& Soc. POL'y 3 (2011), available at https://www.law.berkeley.edu/files/Secure_Communities_by_the_Numbers.pdf. 
noncriminal or low-level offenders. ${ }^{23}$ And DHS took the strict position on Secure Communities that it could access all fingerprints submitted to the FBI by local law enforcement officials even without the permission of state and local officials. ${ }^{24}$ In fact, Secure Communities casts a wide net and scoops up the fingerprints of everyone not born in the United States, whether or not they pose a criminal risk. ${ }^{25}$ For example, an abused woman in San Francisco worked up the courage to call police, but she was arrested as well because the police saw a "red mark" on the alleged abuser's cheek. ${ }^{26}$ The charges against her were dropped, but her fingerprints were already forwarded to ICE under the Secure Communities program, and she faced deportation. ${ }^{27}$ This case was an exact replica of one that occurred in Maryland. ${ }^{28}$

\section{Silent Raids}

Soon after Janet Napolitano took over as Secretary of the Department of Homeland Security (DHS) in 2009, she made clear that the gun-toting ICE raids of the Bush era did not fit into her enforcement strategy. ${ }^{29}$ That turned out to be true for a while. ${ }^{30}$ Instead, she would be targeting employers who hired undocumented workers. ${ }^{31}$

Targeting employers presumably is based on enforcing employer sanctions laws that have been on the books since the Immigration and Reform Control Act of 1986 (IRCA). ${ }^{32}$ However, the Obama administration's focus-on-employers-rather-than-workers strategy in fact

\footnotetext{
23. Id. at 3,9 .

24. Immigration Policy Center, Secure Communities: A Fact Sheet, AMERICAN IMMigRation CounciL (Nov. 29, 2011), http://www.immigrationpolicy.org/just-facts/secure-communities-factsheet.

25. $I d$.

26. Lee Romney \& Paloma Esquivel, Noncriminals Swept Up in Federal Deportation Program, L.A. TIMES (Apr. 25, 2011), http://www.articles.latimes.com/2011/apr/25/local/la-me-securecommunities-20110425.

27. Id.

28. Shankar Vedantam, Call for Help Leads to Possible Deportation for Hyattsville Mother, WASH. POST, (Nov. 1, 2010), http://www.washingtonpost.com/wp-dyn/content/article/ 2010/11/01/AR2010110103073.html.

29. Secretary Seeks Review of Immigration Raid, N.Y. TIMES (Feb. 26, 2009), http://www.nytimes.com/2009/02/26/washington/26immig.html?_r=0.

30. See infra notes $138-81$ and accompanying text.

31. Secretary Seeks Review of Immigration Raid, infra note 114.

32. Peter Brownell, The Declining Enforcement of Employer Sanctions, Migration INFORMATION SOURCE (Sept. 1, 2005), http://www.migrationpolicy.org/article/declining-enforcementemployer-sanctions.
} 
falls squarely on the shoulders of the workers. ${ }^{33}$ Immigration raids at factories and farms were replaced with a quieter enforcement strategy: sending federal agents to scour companies' records for undocumented immigrant workers. "While the sweeps of the past commonly led to the deportation of such workers, the 'silent raids,' as employers call the audits, usually result in the workers being fired, but in many cases they are not deported." The idea is that if the workers cannot work, they will self-deport, leaving on their own. However, they actually do not leave because they need to work. They become more desperate and take jobs at lower wages. Given the increasing scale of enforcement, this can lead to an overall reduction in the average wage level for millions of workers, which is, in effect, a subsidy to employers. Over a twelve-month period, ICE conducted audits of employee files at more than 2900 companies. "The agency ... levied a record $\$ 3$ million in civil fines [in the first six months of 2010] on businesses that hired unauthorized immigrants, according to official figures." Thousands of workers were fired.

"Employers say the audits reach more companies than the work-site roundups" of the Bush administration. "The audits force businesses to fire every suspected" undocumented worker "on the payroll—not just those who happened to be on duty at the time of a raid-and make it much harder to hire other unauthorized workers as replacements." Auditing is effective in getting unauthorized workers fired for sure.

Whether the Obama or Bush administrations, or the Clinton administration before them, actually want to stop migration to the United States or imagines that this could be done without catastrophic consequences is doubtful. More likely, the workers are being used as pawns. The very industries they target for enforcement are so dependent on the labor of migrants they would collapse without it. Instead, immigration policy and enforcement consigns those migrants to an "illegal" status, and undermines the price of their labor. Enforcement is a means for managing the flow of migrants and making their labor available to employers at a price they want to pay.

In 1998, the Clinton administration mounted the largest sanctions enforcement action to date, in which agents sifted through the names of 24,310 workers in forty Nebraska meatpacking plants. They then sent letters to 4,762 workers, saying their documents were bad, and over 3,500 were forced from their jobs. Mark Reed, who directed "Operation

33. Material accompanying footnotes 33 through 34 is the Author's analysis of the Silent Raids as previously published in David Bacon and Bill Ong Hing, The Rise and Fall of Employer Sanctions, 38 FORDHAM URB. L.J. 77, 80 (2010). 
Vanguard," claimed it was really intended to pressure Congress and employer groups to support guest worker legislation. "We depend on foreign labor," he declared. "If we don't have illegal immigration anymore, we'll have the political support for guest workers." 34

\section{E. Targeted Enforcement Operations}

Unfortunately, the Obama administration's commitment to not engaging in Bush era-type raids was impermanent. For example, in New Orleans in 2013, ICE began waging war on the Latino immigrant community, using raids with suspicious racial effects. ${ }^{35}$ The circumstances of the raids were every bit as disturbing as Bush raids.

In the summer of 2014, I spoke with two men in ICE detention who were swept up in a raid at an auto-body shop under the socalled Criminal Alien Removal Initiative (CARI). ${ }^{36}$ On May 13, 2014 Wilmer and Yestel were arrested when ICE conducted a sweeping workplace raid of a Latino auto shop in a heavily Latino suburb of New Orleans. Yestel and Wilmer told me how ICE agents and local police surrounded the auto shop, blocking off all exits and grabbing all Latinos in sight, including workers and customers, men and women. Wilmer was a mechanic at the shop who was working on repairs, while Yestel was a customer who just happened to be at the shop getting his car repaired. After being detained, their fingerprints were processed with a high-tech machine in the back of the ICE van. Both men were then arrested, and neither had seen their homes or partners for weeks.

Under CARI, ICE squads-sometimes accompanied by local police-have been raiding apartment complexes, grocery stores, laundromats, Bible study groups, parks, and anywhere else Latinos might gather. The officers make stop-and-frisk type arrests based on racial profiling and the indiscriminate mobile fingerprinting. The raids make daily routines such as going to buy groceries or bringing the car to get repaired a terrifying task that can lead to deportation.

34. Id.

35. See generally, SaKet Soni et al., The Criminal Alien Removal Initiative in New ORLEANS (2013), available at http://www.nowcrj.org/wp-content/uploads/2008/11/CARI-reportfinal.pdf.

36. The analysis of "Targeted Enforcement Operations" as illustrated by the story of Wilmer Irias Palma and Yestel Velasquez accompanying footnotes 36 through 37 was previously published in Bill Ong Hing, Civil Rights Abuse: Evil Nature of Obama Deportation Machine in New Orleans, IMMIGRATIONPROF BLOG (Aug. 7, 2014), http://www.lawprofessors.typepad.com/immig ration/2014/08/civil-rights-abuse-evil-nature-of-obama-deportation-machine-in-new-orleans.html 
While the CARI program name suggests that "criminals" are the target, in fact these raids are racial profiling-based area sweeps. Wilmer Irias Palma and Yestel Velasquez were arrested because they have prior deportation orders - they do not have criminal records - not even traffic tickets. Wilmer and Yestel arrived after Hurricane Katrina to help with the reconstruction. Both men did demolition and clean-up, exposed to hazards and surrounded by chemicals. The waste smell was awful, and they often got sick and developed skin rashes. Many Latino workers they knew suffered serious injuries on the job. Some workers died. Still, Wilmer and Yestel were happy to help rebuild the city and aid its economic growth. They, like other Latinos, settled in New Orleans and started families. They were happy that former residents were able to return to the city and live with dignity after so much destruction. Now, the Latino workers who made that possible feel hunted and treated like trash.

In November 2013, brave immigrant workers and community leaders exposed the destructive CARI community raids in a protest. And shortly after their arrest in May, Yestel and Wilmer courageously came forward to expose the ongoing ICE raids. They filed a civil rights complaint with the Department of Homeland Security Office for Civil Rights and Civil Liberties and asked DHS to end the raids. While their civil rights complaint was pending, ICE promised that their removal would be stayed for a year, but they would remain in detention. During their interviews with DHS civil rights officials, Yestel and Wilmer were even shackled and under ICE surveillance.

Three years earlier in June 2011, ICE announced a Prosecutorial Discretion Policy promising that upstanding residents like Yestel and Wilmer engaged in protecting civil rights would not be enforcement priorities. Under that policy, Yestel and Wilmer should have been granted immediate release from detention - especially as witnesses and victims participating in a civil rights investigation. In fact, like whistleblowers to unseemly official actions, they should be encouraged and protected.

Instead, less than twenty-four hours after Yestel and Wilmer participated in a Washington, D.C., civil rights briefing by telephone, in a shocking development, ICE revoked their stays of removal and announced that they would be deported within days. ICE directly and spitefully retaliated against Yestel and Wilmer for speaking out about civil rights. Eventually, Wilmer was indeed deported, but Yestel was allowed to stay for another year in an inexplicable split decision. Whatever result, this kind of retaliation creates a chilling effect that goes far beyond the individuals involved. 
The fact that these ICE raids continue is deeply troubling. The fact that ICE can retaliate against immigrant civil rights leaders for exposing abuse is even more disturbing. The vengeance raises the concern that this civil rights crisis is not an isolated product of a rogue ICE office in the Deep South, but rather a product of Obama's national deportation policies. The administration continues its record-breaking deportation pace, and as a result of CARI, Louisiana has the highest per capita deportation rate in the country, as well as the highest per capita rate of immigration arrests of any non-border state. The raids, detentions, and deportations show that the administration is either incapable of addressing rampant civil rights violations by its own agents, or is willing to turn a blind eye to a rogue agency in exchange for record-setting deportation numbers.

It turns out that the CARI program in New Orleans is not the only ICE raids undertaken under the Obama administration. Soon after news of the CARI program in New Orleans broke out, immigrants and community advocates around the country reported significant increases of individuals detained as "collateral" arrestees during similar raids. This increase is particularly noticeable in places like New York, Philadelphia, Wisconsin, Washington, Alabama, Massachusetts, Florida and Illinois. Incidents involving "collateral arrests of people with old criminal convictions or prior deportation orders" have sharply increased in Georgia and Connecticut. Arrests and home raids of organizers in places like Arizona have been reported.

ICE officials do not label these policies "raids." Instead, in its terminology, ICE conducts " "targeted enforcement' operations to arrest "priority' individuals who present a danger to the public." In fact, there is no difference. "Targeted enforcement" operations are raids. "In a targeted enforcement operation, ICE stakes out a single home, apartment building, business, or - in some cases - an entire neighborhood in search of its target." ICE agents ask for papers from individuals encountered, arresting and deporting many who were not initially targeted. The ICE Fugitive Operations team and other ICE components conduct the operations under the direction of the local Field Office Director. These operations are not limited to businesses. In the words of one day laborer organizer in New Orleans,

Before ICE used to round people up in the community. Now, they go to people's houses. They show them a picture of a person they usually don't know. Even if the person isn't there, everyone in the house still gets fingerprinted using the biometric machines. The only difference is ICE makes sure to show people a photograph so that they can say it is targeted enforcement and not a raid. 
To make matters worse, ICE has retaliated against community organizers and immigrants who have been advocating against removals and for those being held in custody. An Arizona advocate reports that "[i]n retaliation for organizing, ICE has denied people's visitation rights, gone out of their way to keep people in detention even when granted bond, and even put people's family members in solitary confinement," or denied visitation rights. In Tacoma, Washington, the families of organizers who participated in a detention center hunger strike also suffered retaliation. Family visits are often reduced to 10 or 20 minutes. $^{37}$

\section{F. Removal of Lawful Permanent Residents Without a Fair Hearing}

When President Obama announced his expansive actions in November 2014 to grant deferred action and employment authorization to undocumented parents of U.S. citizens, he emphasized that deportation would be focused on "felons, not families." 38 While this is a catchy phrase, its flaw is obvious:

"People with felonies have families too," said [Abraham] Paulos, whose organization Families for Freedom advocates for families who've been separated by criminal deportation. "That's a false binary [Obama] is setting up," said Tia Oso, the Arizona organizer for the Black Alliance for Just Immigration. Oso pointed out that because blacks in the U.S. are already targeted by the War on Drugs and racial and ethnic profiling by police, partnerships between law enforcement and immigration authorities mean that black immigrants are in detention and criminal deportation proceedings at a rate five times their actual presence in the U.S. undocumented community. ${ }^{39}$

Rithy Yin was a baby when his family fled the killing fields of the Cambodian Khmer Rouge, that took his father's life, and entered the United States as refugees. ${ }^{40}$ In a Seattle inner city neighborhood "plagued with drugs and gang violence... Rithy turn[ed] to the streets to find

\footnotetext{
37. Id. at 13 .

38. Julie Pace, Immigration: Obama Seeks to Focus Efforts on 'Felons, not Families', THE PRESS ENTER (Nov. 20, 2014, 9:56 PM), http://www.pe.com/articles/people-754684-obamaactions.html.

39. Julianne Hing, Who Will Lose Under Obama's Executive Action?, COLORLINES (Nov. 21, 2014, 4:26 PM), http://www.colorlines.com/archives/2014/11/who_will_lose_under_obamas_ executive_action.html.

40. Clayborn D. Tolliver, Jr., One the President's Action Does not Help, THE Hill (Nov. 26, 2014, 10:00 AM), http://www.thehill.com/blogs/congress-blog/civil-rights/225321-one-thepresidents-action-does-not-help.
} 
acceptance," and he was in state prison by the age of eighteen. ${ }^{41}$ While serving his entire ten-year sentence, Rithy "grew up," completing his GED, working in the prison ministry, and providing moral support to new inmates. ${ }^{42}$ However, on his release from prison, Rithy was greeted by an ICE deportation order, even though he is totally unfamiliar with Cambodia, and his mother, siblings, and their families are all in the United States. $^{43}$

Many other Cambodian refugees who have committed crimes have been deported or face the prospect of removal. ${ }^{44}$ All paid the price of their crimes by serving their time in prison, but unlike U.S. citizens, they face the additional punishment of banishment, even though they have strong evidence of rehabilitation and remorse. ${ }^{45}$ Once classified as an aggravated felon (usually for being sentenced to a year or more in prison), their long residence in the United States and the effect of deportation on their families is irrelevant in deportation proceedings. ${ }^{46}$

Consider Lundy Khoy. ${ }^{47}$ Lundy Khoy is facing deportation because of the U.S. immigration law zero-tolerance policy toward aggravated felons. Lundy was born in a Thai refugee camp after her parents fled the genocide in Cambodia. When she was one-year-old, she and her family came to the United States as refugees. Lundy and her parents were granted lawful permanent residence status when Lundy was in kindergarten, but they never filed for citizenship through naturalization because of the expense. In 2000, when Lundy was a 19-year-old freshman at George Mason University, she was stopped by a bicycle cop who asked if she had any drugs. She answered honestly and told the officer that she had seven tabs of ecstasy, but that they were not all for her. She was arrested for possession with intent to distribute. On the advice of her lawyer, she pled guilty, ${ }^{48}$ to spare her family the expense and embarrassment of a trial. She was sentenced to five years in prison.

\footnotetext{
41. $I d$.

42. Id.

43. Id.

44. Bill Ong Hing, Detention to Deportation-Rethinking the Removal of Cambodian Refugees, 38 U.C. DAVIS. L. REV. 891 (2005).

45. Id. at $902-03$.

46. $I d$.

47. The analysis of "Removal of Lawful Permanent Residents Without a Fair Hearing" as illustrated by the story of Lundy Khoy accompanying footnotes 47 through 49 was previously published in Bill Ong Hing, Re-examining the Zero-Tolerance Approach to Deporting Aggravated Felons: Restoring Discretionary Waivers and Developing New Tools, 8 HARV. L. \& POL'Y REV. 141, 14445 (2014).

48. Guilty pleas on advice of counsel are, of course, common. See Padilla v. Kentucky, 559 U.S. 356 (2010) (ruling that criminal defense attorneys must advise noncitizen clients about the de-
} 
Although Lundy was released and placed on probation after serving only a few months in prison, her conviction is an aggravated felony for deportation purposes. In the spring of 2004, Lundy arrived at a regularly scheduled probation appointment to show off her college report card. When she stepped inside the office, she was greeted by her probation officer and Immigrations and Customs Enforcement agents who were targeting removable agents on active probation. She was instructed to hand over possessions and stand spread eagle against the wall; they handcuffed and transported her to Hampton Roads Regional Jail in Portsmouth, Virginia. Given her aggravated felony conviction, an immigration judge ordered Lundy deported without hearing evidence of her childhood in the United States, current family situation, her educational pursuits, and her perfect cooperation during her probation. Lundy remained in ICE custody for nine months, while the United States attempted to deport her to Cambodia. However, only because Cambodia is taking its time in issuing travel documents for Lundy, ICE has released her pending the documents.

Now in her early thirties, Lundy is trying to lead a normal life as she awaits her fate. Having been born in a Thai refugee camp and lived in the United States since the age of one, she finds it hard to imagine being removed to Cambodia, a country with which she has no familiarity or family ties; all her relatives live here. She is now trying to complete her bachelor's degree, works full-time as a college enrollment counselor, and volunteers for local charities, including Habitat for Humanity and the Boys and Girls Club. If Lundy had been born in the United States (like her two siblings) or if her parents had become naturalized citizens before Lundy turned 18 (automatically giving her citizenship), she would not be on the deportation list.

Lundy lives in Washington, DC, a few blocks from her sister, Linda, who is only eighteen months younger, but is a U.S. citizen because she was born after the family arrived in the United States. The two are inseparable. They grew up sharing a bed and a bedroom, until Lundy started college. Linda is Lundy's most ardent supporter. They cook together, go out together, laugh together, and cry together; they think of each other as soul mates. They share intimate details about each other's' lives. Linda joins Lundy in speaking out about

portation risks of a guilty plea). When the law is unambiguous, attorneys must advise their criminal clients that deportation "will" result from a conviction. Id. at 380. When immigration consequences are unclear or uncertain, attorneys must advise that deportation "may" result. Id. 
current deportation policies, and the two are working with community based organizations in Washington, DC, and Philadelphia to seek a legislative solution for those who are in the same shoes as Lundy. When Lundy is feeling depressed or worried, Linda provides emotional support to bring Lundy back from those lows. Linda cannot imagine what her life would be like if Lundy was deported to Cambodia.

"We have a glimpse of what Lundy Khoy would accomplish with a second chance, as she continues working as a college counselor, pursuing her degree, and engaging in volunteer work. Instead, she awaits a deportation notice, foreclosed of an opportunity to plead for a second chance." "Many deported noncitizens like Lundy are removed to countries where they have virtually no ties. However, the federal courts are not in a position to intervene, because any noncitizen convicted of an aggravated felony is subject to deportation from the United States without statutory relief." 49

Of course, the deportation of so-called criminal immigrants who deserve a second chance is not limited to Cambodian refugees. Every day DHS deports lawful permanent residents from all over the world who have committed crimes. ${ }^{50}$ More often than not, family separation results, as U.S. citizen or lawful resident parents, spouses, and children remain. ${ }^{51}$

The thought, or perhaps lack of thoughtfulness, behind some deportations is numbing. For example, when I heard about the deportation of Tatyana Mitrohina, ${ }^{52}$ the circumstances were hard to fathom.

Tatyana was born in Russia in 1978. She was born with multiple health problems, including heart defects. Both of her hands are small and partially deformed. She has a similar problem with her feet. Her parents abandoned Tatyana immediately after birth. She spent the first ten years of her life in hospitals, rehabilitation facilities, and a boarding school for disabled children without contact with her parents. She underwent several surgical procedures to correct her birth defects, but the abnormalities of her hands and feet were never fully corrected.

\footnotetext{
49. $I d$.

50. See generally, InTERnational Human Rights Law Clinic ET AL., In the Child's Best Interest? The CONSEQuences of Losing A LaWful ImMigrant Parent to Deportation (2010), available at $\mathrm{http}: / / \mathrm{www}$. law.berkeley.edu/files/Human_Rights_report.pdf

51. Id. at 4 .

52. The analysis of "Removal of Lawful Permanent Residents Without a Fair Hearing" as illustrated by the story of Tatyana Mitrohina accompanying footnotes 52 through 53 was previously published in Bill Ong Hing, Systemic Failure: Mental Illness, Detention, and Deportation, 16 U.C. DAVIS J. INT'L L. \& POL'Y 341, 341-42 (2010).
} 
As with most children, these first ten years of Tatyana's life had profound impact on her emotionally and psychologically. She had multiple caretakers and had no one to whom she felt attached. She felt rejected and abandoned by her biological family. When asked about the effect this period of her life had on her, Tatyana explained: "I didn't like to be touched, I couldn't stand to be touched or hugged." A psychologist who evaluated Tatyana observed: "Ms. Mitrohina demonstrates a range of psychopathology frequently observed as a sequel of early neglect, abandonment and institutionalization, emotional rejection, and physical trauma."

When she was about seven years old, after she was released from the hospital, Tatyana's maternal grandmother took responsibility for her. At the time, Tatyana was unaware that she had a family. A year or so later, her father began to visit, and about three years later, he decided to bring Tatyana back into the family.

Her father brought Tatyana home to live with family because that made the family eligible for a better apartment in Russia. The atmosphere in the home was hostile, chaotic, and filled with conflict. Tatyana's mother was opposed to her return and was openly hostile and critical of Tatyana. Tatyana was constantly beaten by both parents. Her parents continually told her that she was "inadequate and worthless." The psychological evaluation reported a "history of neglect, physical and verbal abuse as a child and one attempted molestation between the age of 8 and 10."

The tense home life led to the disintegration of the family. Her parents divorced when Tatyana was twelve. Her father departed, and Tatyana was left with her mother who did not want her. So when Tatyana turned fourteen, her grandmother, who had legal custody, signed adoption papers. Oldrich and Ruth Gann of Sonoma, California, who were 68 and 63 years old, respectively, at the time, adopted Tatyana and brought her to the United States in 1993.

Tatyana had difficulty adapting to her new family. She constantly felt that she could not live up to her adoptive parents' expectations. Her dislike of being touched or held persisted into her late teens. She had difficulty addressing her new parents as "mom" and "dad." To Tatyana, the relationship was a "mismatch" and she did not get along with her adoptive parents from the start.

Concerned with the conflict, Tatyana's adoptive parents had her evaluated by a psychologist. The psychologist prescribed medication, and her parents threatened to send Tatyana back to Russia if she did not take the medication. Tatyana did not appreciate the psychological 
treatment and argued with her parents; her parents often called the police after these altercations erupted. Tatyana felt trapped and became depressed and angry. An argument in 1999 led to a call to the police. When the police arrived, Tatyana was so upset that she kicked her adoptive father in the leg in front of the police officer. Tatyana was taken into custody, but charges were later dismissed.

In 2000, while still living with her adoptive parents, Tatyana threatened to kill herself. She was not arrested, but she was taken to a mental health facility for three days. She eventually moved out of her parents' house. Since then, Tatyana's adoptive father has passed away and she has not maintained contact with her adoptive mother.

After moving out, Tatyana rented a room from a young man with whom she later became emotionally involved. She soon noticed that he mistreated his six-year-old son. On one occasion, the child was complaining about a stomach pain, and the father refused to do anything, so Tatyana called an ambulance.

After that, the landlord was abusive toward her for eighteen months. In 2002, after an argument, Tatyana kicked him several times. He called the police, and she was arrested and pled guilty to a misdemeanor battery. Tatyana received thirty-six months formal probation, and was ordered to pay fines and fees, complete a 52-week batterer's program, maintain employment, and complete community service. She successfully completed all the terms of her sentence.

Tatyana held a variety of jobs in the United States and attended junior college. She worked at the Sonoma Market, Baskin Robins, and provided care for the elderly through an agency. She lost these jobs because of anger management problems. She worked for a time caring for elderly residents at an assisted living facility. Tatyana admitted that she had kicked an elderly patient three or four times while working at this facility. The patient did not report the incident because she suffered from Alzheimer's Disease. Tatyana took classes at a junior college over a two-year period from Spring 2005 to Spring 2007.

Tatyana became pregnant by a man named John Carter Goode. The baby was born on October 17, 2005. Although Tatyana tried to get him involved, the father of the child was never involved in the child's life. Tatyana had no one to rely on for financial help or other assistance in the child's upbringing. Her probation officer noted that Tatyana lacked "a support system for parenting and when she needs a break, she has been unable to secure a reliable babysitter." Although Tatyana was eventually convicted of child abuse, the child protective services investigator observed that the child was "healthy, had suffered no long-term injury, 
and appeared to be slightly advanced for his chronological age." When her son was a year and a half old, Tatyana got a job at Metro PCS, a wireless phone company, in an attempt to get off of welfare assistance. She lost that job when she was arrested in June 2007.

On June 26, 2007, when the child was just under two years old, the child spilled some water and then grabbed a roll of paper towels to clean up the mess. He scattered paper towels all over the floor. According to a pre-sentence report:

Tatyana then grabbed the victim, took him to the bedroom, and threw him on the bed to give him a "time out." She then began to slap the victim with her hands, on his head and legs, approximately ten times. Tatyana stated: "I was yelling at him like he was 20," even though she knew he could not understand. The defendant explained that she did not stop when she should have, and left a bruise and mark on his face. Victim John Doe was screaming and crying as she hit him.

Tatyana commented that the instant matter was not the first time she slapped victim Joe [sic] Doe, but indicated that it was the worst because it left a mark. She said she would become angered when John Doe, as a newborn, "threw up" or "pooped" too much. She admitted that she had been hurting victim John Doe since he was born, and had become more physical with him as he grew older. At times, she slapped him and threw him on the ground. She also admitted that approximately one year earlier, she had hit John Doe in the face and caused a large, visible bruise under his eye.

Tatyana then took her child to a day care center, explained to an employee that she had become frustrated with her son at home and had struck him with her bare hands. She left the child at the day care and went to her job. The child was visibly bruised on his left temple. A county worker interviewed Tatyana later that day, noting that she "did not cry, and appeared very cold and nonchalant about the abuse. She was only concerned about being arrested and not about the condition of her son, and never once asked if he had gone to the hospital or if he was alright."

As a result of this incident, the child was removed from Tatyana's care, and child abuse charges were brought. Tatyana pled guilty and was sentenced to 120 days in jail and four years on probation. Ultimately, she was only required to serve about a month in jail. A probation officer who interviewed Tatyana while she was in custody noted that she was very remorseful and forthcoming throughout the interview, noting that she "has struggled with shame and guilt while in custody, and has spent much time in introspection." When she was first taken into custody, 
Tatyana was very upset and she cried a lot. The mental health staff in the county jail determined that she was likely suffering from depression, perhaps due to a chemical imbalance in her brain. So she was prescribed Zoloft. Zoloft is an antidepressant drug, used to treat depression, obsessive-compulsive disorder, panic disorder, anxiety disorders, and post-traumatic stress disorder (PTSD).

While she was in jail for the child abuse conviction, Tatyana was on a "no mix" status, and was unable to avail herself to counseling and other resources normally offered to inmates. In spite of that status, she sought to participate in anger management correspondence courses. She took responsibility for her actions and was remorseful. She was committed to doing whatever was required to successfully reunite with her son. She testified, "My baby is first in my life now. I know I need to get help myself in order to take care of my baby."

The child was placed into foster care and became the subject of juvenile court proceedings. In early October 2007, the juvenile court ordered that family reunification services be offered to Tatyana. The court's goal was to reunify Tatyana with her child. Tatyana was ordered to participate in a number of different services, including counseling and domestic violence programs. The problem was that by then, Tatyana was in ICE custody, unable to comply with the juvenile court's order.

If Tatyana had been a U.S. citizen, after her month in jail, she would have been released from custody. However, she was a lawful permanent resident alien who now had committed a deportable offense. So ICE officials took custody of Tatyana upon her release from jail and kept her in custody pending removal proceedings. By the time her removal hearing took place, she had been in custody for four months.

Tatyana wanted to abide by the juvenile court's mandate because she had the utmost desire to resolve her personal problems and regain custody of her son. The problem, of course, was that Tatyana was in ICE custody facing removal proceedings, so she could not follow the juvenile court's order. Being out of ICE custody would have given her the opportunity to straighten out and have a chance at reunifying with her son. If she had been able to do that, her posture in the deportation case would have been far different.

In determining whether Tatyana merited a favorable exercise of discretion, the immigration judge felt that he had to balance the positive factors in Tatyana's case against the negative ones to determine whether the granting of relief was "in the best interests" of the country. In choosing to interpret the balance unfavorably and conclude that Tatyana was not deserving of a waiver, the judge used the following reasoning: 
There are factors about the respondent's life that evoke genuine sympathy. She has to live her life with visibly deformed hands. She spent her first seven years in a hospital, and was essentially abandoned by her birth parents. She was in an abusive relationship, and she testified that the father of her child has never played any meaningful role in his life. In addition, if the respondent is removed to Russia, she may find it difficult to support herself, and has no real family to rely upon. She also points out that if she is removed her son will grow up as an orphan, in much the same way she did. She wrote letters to the sentencing judge in the Superior Court and to this court, expressing her remorse for what she has done and vigorously arguing that she will not break the law or hurt her son again. Sonoma County, where the most recent offense occurred, has ordered respondent (if she is released) to participate in a number of counseling programs in order to see whether respondent can be reunited safely with her child.

Balanced against those factors, however, is the fact that respondent has repeatedly decided to address her frustrations and disappointments with violence. She assaulted her stepfather, her ex-boyfriend[,] an elderly disabled patient who was entrusted to her care, and on many occasions her very young child. She said she got physical with this baby "a few times a month." She hit him in the face and caused a bruise under his eye. She threw him on the bed and beat him while he screamed. She struck him in the temple, an extraordinarily dangerous act, and did so with such force that it caused visible swelling and bruising. The victim was only twenty months old.

This was not an isolated incident, but a repeated response to situations of stress. The difficulty is that no person can eliminate situations of stress from their lives, and this pattern of behavior gives this court grave concern that the respondent may act in a violent or dangerous way in the future. Of particular concern is the fact that not only has the respondent assaulted able-bodied adults, but highly vulnerable persons, namely the elderly patient at the nursing home and, with frequency, her small child.

The respondent's most recent psychological evaluation revealed that she had gone through a course of anger management in 2002 along with psychotherapy on a weekly basis, but that she had resisted previous therapeutic interventions. She "perceived parenting instructions as an intrusion and interference with her doing things her own way." The psychologist who interviewed her found "a chronic angry undercurrent during the interview as well as some difficulty with an overly idiosyncratic way of perceiving. She [respondent] tended to distort reality to meet her needs or misidentify the salient aspects of a situation. It wasn't at the level of psychosis, but was at a level that would significantly interfere with her ability to accurately perceive and cope with everyday life and interactions." She had no symptoms of underlying neurological impairment, but "evidenced very little insight regarding her thoughts, feelings and behaviors." The report states that persons with respondent's psychological profile have "a tendency to act 
out in an impulsive, aggressive manner, display poor judgment, and do not seem to learn from their experiences." Such persons "often agree to treatment to bring about an outcome they desire or avoid some consequences, but are likely to terminate their participation in interventions before they can have an effect." The report concludes "[o]verall, the prognosis for Ms. Mitrohina benefiting from services is poor."

After considering all relevant factors, this Court finds that the negative factors far outweigh the positive in the present case. The respondent has not shown that it is in the best interests of the community that she remain in the United States. Indeed there is a real concern that she is a danger to others.

One of the more troubling aspects of the immigration judge's decision is that his order essentially was a family law decision to sever the parent-child relationship. The denial of Tatyana's cancellation application foreclosed her from following the reunification conditions of the state court, thereby making termination of the relationship a fait accompli. The sad irony is that had we been able to hit a pause button on the removal proceedings and release Tatyana to follow the reunification plan (parenting classes, anger management, mental health medication), and if she had been able to regain custody of her son or at least make clear progress, the outcome of the deportation case might have been different once the hearing resumed. The immigration judge's decision blocked these possibilities, even though he lacked the necessary family law expertise to make such conclusions.

Unlike the immigration court, the state superior court was acting in one of its areas of expertise in conjunction with the probation department. In making their determination, the probation officer and state court made their choices, taking into account Tatyana's criminal history and concluding that offering reunification services was appropriate. This is important because terminating parental rights is a grave matter, and the state's main concern is the best interest of the child. Significantly, reunification services are not to be provided if a parent is suffering from a mental disability that renders him or her incapable of utilizing those services. In essence, the immigration court decided not to defer to the expertise of the state court, instead making its own decision-without the benefit of experience or special expertise-to determine that it was in the best interests of Tatyana's child to be taken from Tatyana permanently. 
Tatyana was born in Russia with heart defects and deformed hands. "She was rejected by her parents for many years, spending her infancy in hospitals and institutions." Later she was abused by her parents, then abandoned by them.

She immigrated to the United States as a young teen, adopted by U.S. citizens. After more than a decade, she had a child of her own, whom she abused. Tatyana was diagnosed with mental illness. Although she was convicted of child abuse, the state court recommended medication, counseling, and a chance to regain custody of her child. But ICE took over, and Tatyana was removed from the country.

The parent-child relationship was severed. ${ }^{53}$

\section{G. UAC Enforcement Prioritization}

A humanitarian crisis at the border captured the attention of the nation last summer. ${ }^{54}$ As of June 30, 2014 almost 60,000 unaccompanied alien children from Honduras, El Salvador, Guatemala, and Mexico reached the southern U.S. border. ${ }^{55}$ By the end of 2014, a total of 90,000 was expected. ${ }^{56}$

The sharp increase has generated tremendous media coverage and speculation by elected officials and others about the reasons. However, many of the explanations are overly simplistic. Some say this surge is the result of immigration reform promises or administrative reforms in enforcement that sent encouraging signals to Central Americans, suggesting that they may enjoy a "de facto amnesty" if they get across the Mexico border. Others said the children are being drawn by rumors about special protections for migrant children by the Administration, and point to the Deferred Action for Childhood Arrivals (DACA) program announced in 2012.

In reality, the problem is enormously complex. The Women's Refugee Commission found through interviews with 151 such youth that their migration arose out of longstanding, complex problems in their

53. Id.

54. See, e.g., Editorial, The New Crisis at the Border: Undocumented and Unaccompanied Minors, L.A. TIMES (June 15, 2014), http://www.latimes.com/opinion/editorials/la-ed-immigrationminors-20140615-story.html.

55. Lauren Shapiro and Eugene Kiely, Surge of "Unaccompanied Children," FACTCHECK.ORG (July 18, 2014), http://www.factcheck.org/2014/07/surge-of-unaccompanied-children/.

56. The Author's analysis of UAC Enforcement Prioritization accompanying footnotes 56 through 57 was previously published in Bill Ong Hing, Playing Politics With the Lives of Unaccompanied Alien Children, HuFFINGTON POST (June 26, 2014), http://www.huffingtonpost.com/bill-onghing/playing-politics-with-the-unaccompanied-aliens_b_5530766.html. 
home countries - that is, the growing influence of youth gangs and drug cartels, targeting of youth by gangs and police, gender based violence, rising poverty, and continuing unemployment. Over 77 percent of the participants stated violence was the main reason more children were fleeing their countries.

Violence in the home countries is a definite factor. Honduras, where the largest numbers of unaccompanied minors are coming from, has become one of the most dangerous countries in the world. In 2011, Honduras became the country with the highest murder rate in the world. Homicide rates in El Salvador are only marginally lower than in Honduras, with 66 individuals killed for every 10,000 inhabitants.

Children are at a greater risk of gang violence. Collaboration between drug cartels and gangs has led to a significant increase in violence, with children and teens being the primary targets. According the University of Democracy, Peace and Security, 920 Honduran children were murdered between January and March of 2012. In El Salvador, gangs have increasingly targeted children at their schools, resulting in El Salvador having one of the lowest school attendance rates in Latin America.

Human and drug trafficking is occurring. Due to the influence of cartels in Mexico and at the border, the current migratory experience is very much connected with human and drug trafficking. The United Nations High Commissioner for Refugees (UNHCR) reported that organized criminal groups coerce children into prostitution and to work as hit men, lookouts, and drug mules. Drug traffickers may target minors in their home country and force them to traffic drugs across the border and once they are in the United States. Because these youth often travel alone and are escaping death in their home countries, they are often faced with no choice but to carry drugs or work for drug cartels in order to across sic the border. Gang and drug trafficking in Central America are also increasingly recruiting girls to smuggle and sell drugs in their home countries, using gang rape as a means of forcing them into compliance. Many gangs are targeting younger girls, some as young as nine-yearsold, for rape and sexual assault. Gangs also use the threat of rape as a tactic to gain money through extortion and kidnapping. ${ }^{57}$

57. Id. 
1. Detention of Unaccompanied Children

The Office of Refugee Resettlement (ORR), a branch of the Department of Health and Human Services, is the federal agency responsible for the care and custody of unaccompanied children. ${ }^{58}$ Under the William Wilberforce Trafficking Victims Protection Reauthorization Act of 2008, unaccompanied, children from non-contiguous countries must be transferred to ORR custody within 72 hours of their arrest. ${ }^{59}$ For several years, ORR has operated temporary shelters throughout the United States to house children while ORR caseworkers sought to reunify them with family members or family friends in the United States. ${ }^{60}$ In response to the dramatic increase in numbers of children apprehended by Customs and Border Patrol, ORR opened three large facilities housed on military bases: Joint Base San Antonio - Lackland in San Antonio, TX; Fort Sill Army Base in Oklahoma and Port Hueneme Naval Base in Ventura, California. ${ }^{61}$ Advocates had raised significant concerns about the conditions in which children were held at these facilities and the difficulty attorneys and legal workers had in gaining access due to security procedures at these military facilities. ${ }^{62}$

\section{Detention of Families}

In a change in policy, Immigration and Customs Enforcement (ICE) began detaining families apprehended at the border, rather than releasing them from custody to appear for removal proceedings at a later date. ${ }^{63}$ ICE opened a family detention center in Artesia, New Mexico, in late June $2014^{64}$ and opened a second family detention center in Dilley, Texas, in December. ${ }^{65}$ Advocates soon reported serious due process concerns regarding the way in which cases were being handled in Artesia. ${ }^{66}$ Concerns also were raised about how credible fear screening

58. Sarah Bronstein, Update on Unaccompanied Children and Families, CATHOLIC LeGAL IMMIGRATION NETWORK, Aug. 2014, https://www.cliniclegal.org/resources/articles-clinic/updateunaccompanied-children-and-families-august-2014.

59. Id.

60. $I d$.

61. $I d$.

62. Id.

63. $I d$.

64. Id.

65. Id.

66. $I d$. 
interviews for asylum were being conducted. ${ }^{67}$ These interviews determine whether the adult family member will be given the opportunity to have her asylum claim heard before an immigration judge. ${ }^{68}$ Other problem areas include hearings being conducted remotely via video teleconferencing and lack of access to counsel. ${ }^{69}$

A message from a pro bono attorney who traveled to assist detainees in Artesia contains typical observations:

On average our days in Artesia ran from 5:30am to 1:30am, logging in around 4 hours of sleep a day. We entered the facility in the cool dawn hours and left at dusk. In between those hours, when we would step out of the attorney trailer or the court trailer to move between trailers, the bright sun and the bland backdrop of the white trailers that comprise the detention center and the neutral Southwest landscape were blinding. After leaving the detention center, we went to the church to meet together to troubleshoot cases, receive updates, and doll [sic] out the next day's cases and workload. After the group meeting, we would begin preparing our cases for the next day.

Our team filled a variety of roles. At the detention center, some of us would meet with women and kids in the attorney trailer to prepare their cases. The list of these consultations was on average around 60. Others would be in court representing the women in their bond and asylum hearings in two court dockets that averaged around 15 cases a court. Still others would stay behind at the community church to prepare innumerable filings.

The women we saw were mostly from El Salvador, Guatemala and Honduras. They were all fleeing either gang or domestic violence or both. They shared stories of kidnapping, rape, abuse, extortion and threats. The weight that these women carry is profound. Most of the women came to the attorney trailer for consultations with their children. They often have to recount these horrific stories of rape, domestic violence, abuse, and other threats within earshot of their children. We would do our best to remove the children during these moments, but even separating mom from child(ren) was cruel in itself. As a distraction, ICE would put on a children's video and tear out pages of coloring books and give the children crayons that they have to return when they leave the legal trailer.

Most of the children had coughs, some had sores on their faces, one kid had a growth on his face. There have been chicken pox outbreaks here, leading to quarantines. Many of the children who are old enough to be weaned from bottles have regressed to bottles. Some moms reported
67. Id.
68. Id.
69. Id. 
their children were sleeping for distressingly long hours. I read medical records of a 5 year old reporting to the clinic here that expressed that his level of pain was between 7 to 8 on a scale of 10 .

We heard that some of the little boys have started to pretend they are ICE agents, mimicking them at count (when the guards count the detainees to confirm that everyone is still there).

Another disturbing observation from our team is how quiet the kids are in Artesia. All day we are surrounded by them either in our consultation area in the detention center or in court. They all seem so sedated and low energy. I spent two days working with one mother and her 16 month old. The child's face was always tear-stained and yet he never made a peep or fussed. ${ }^{70}$

\section{The Use of "Rocket Dockets"}

Another significant development is the implementation of expedited removal proceedings, so-called "rocket dockets," for unaccompanied children and families who have been [recently] released from custody. ${ }^{71}$ Relatives or close family friends can sponsor children in order to have them released from custody. Their deportation cases are then transferred to the immigration court near the relative or family friend. Rocket dockets have been rolled out in immigration courts across the country. ${ }^{72}$ Children and families have been given as little as three days' notice of their court hearing date, severely limiting their ability to find counsel. $^{73}$ Continuances (periods of time in between hearings) are being granted for very short periods of time - in some instances as little as a week - to find an attorney. ${ }^{74}$

On July 22, 2014, Dana Leigh Marks, President of the National Association of Immigration Judges, sent a letter to Sen. Harry Reid, U.S. Senate Majority Leader, and Sen. Mitch McConnell, U.S. Senate Minority Leader, expressing "serious concerns" about immigration judges' caseloads and the use of expedited procedures in children's cases. ${ }^{75}$ Coordinated efforts by service providers to respond to the rocket

70. Helen Lawrence, Artesia On Our Minds-An Immigration Attorney's Diary of a Detention Camp, Silicon VAlley De-BUG (Oct. 21, 2014), http://www.siliconvalleydebug .org/articles/2014/10/21/artesia-my-mind.

71. Sarah Bronstein, Update on Unaccompanied Children and Families, CATHOLIC LEGAL IMMIGRATION NETWORK (Aug. 2014), https://www.cliniclegal.org/resources/articles-clinic/updateunaccompanied-children-and-families-august-2014.

72. Id.

73. $I d$.

74. Id.

75. Id. 
dockets in many parts of the country have helped, but the stress and pressure on these providers has been immense. ${ }^{76}$ Some jurisdictions, including the State of California and San Francisco County, have tried to help by appropriating funds for community organizations to hire additional staff. ${ }^{77}$

\section{Revisions to Credible Fear Standards}

As the surge in UACs began in early 2014, USCIS - whose asylum office handles asylum cases - revised its Lesson Plan for officers on how to determine whether asylum applicants who make it to the border meet the credible fear screening standard. ${ }^{78}$ The new credible fear standards are quite misleading and inappropriate. The language and tone instruct asylum officers to impose a burden on applicants ${ }^{79}$ that surpasses the well-founded fear standard established by the Supreme Court in INS v. Cardoza-Fonseca, ${ }^{80}$ when in fact the actual standard should be more deferential than the well-founded fear standard.

As the Lesson Plan correctly points out, the function of credible fear screening is "to quickly identify potentially meritorious claims to protection and to resolve frivolous ones with dispatch.... If an alien passes this threshold-screening standard, [the] claim for protection... will be further examined by an immigration judge...." ${ }^{, 1}$ This is consistent with the statutory structure. Under 8 U.S.C. $§ 1225(b)$, if "the alien indicates either an intention to apply for asylum ... or a fear of

76. Lauren Roberts \& Renée Schomp, The Longest Hug Ever, ONEJUSTICE Blog (Dec. 12, 2014), https://www.onejusticeblog.wordpress.com/category/pro-bono-services-to-help-californiansin-need/.

77. Alex Dobuzinskis, California sets up fund for legal representation of immigrant children, REUTERS (Sept. 27, 2014), http://www.reuters.com/article/2014/09/28/us-usa-immigrationcalifornia-idUSKCN0HN00B20140928; Elise Foley, San Francisco Supervisors Vote To Provide Lawyers For Kids Facing Deportation, HufFIngton Post (Sept. 17, 2014), http://www.huff ingtonpost.com/2014/09/17/san-francisco-immigrants_n_5836230.html.

78. U.S. Citizenship AND Immigration SERvices - RAIO, ASylum Division OfFicer Training Course: Credible Fear 44 (Feb. 28, 2014), available at http://www.cmsny.org/wpcontent/uploads/credible-fear-of-persecution-and-torture.pdf [hereinafter THE LESSON PLAN]; USCIS Amends Credible Fear Lesson Plans, CATHOLIC Legal IMMigration Network, https://www.cliniclegal.org/resources/uscis-amends-credible-fear-lesson-plans (last visited May 25, 2015).

79. THE LESSON PLAN, supra note 78, at 44 (establishing that "[i]n order to establish a credible fear of persecution or torture, the applicant must show a 'significant possibility' that he or she could establish eligibility for asylum").

80. 480 U.S. 421, 430 (1987) ("the 'well-founded fear' standard governs eligibility for asylum").

81. THE LeSSON Plan, supra note 78, at 11 (citing Immigration and Naturalization Service, Regulations Concerning the Convention Against Torture, 64 Fed. Reg. 8478, 8479 (Feb. 19, 1999)). 
persecution, the officer shall refer the alien for an interview by an asylum officer." 82 Then if the asylum "officer determines at the time of the interview that an alien has a credible fear of persecution ... the alien shall be detained for further consideration of the application for asylum." ${ }^{\prime 3}$ Thus, the credible fear process clearly is a screening process for potentially meritorious asylum claims versus frivolous ones. Structurally and explicitly, the alien certainly does not need to establish the asylum claim at this point; a potentially meritorious claim at this juncture is all that is necessary. ${ }^{84}$

Thus, the standard and burden for credible fear-a threshold screening stage - must be lower than establishing an actual meritorious claim for asylum. At this credible fear review, the asylum officer can only screen out frivolous claims. ${ }^{85}$

Since the standard for credible fear is structurally less rigorous than the standard for asylum, in order to adequately appreciate and grasp the correct credible fear standard, one must know what the standard is for asylum. In order to qualify for asylum, the applicant must meet the definition of refugee set forth in 8 U.S.C. $\S 1101$, by establishing "a well-founded fear of persecution." 86 In INS v. Cardoza-Fonseca, the Supreme Court explained the well-founded fear standard: "[S]o long as an objective situation is established by the evidence, it need not be shown that the situation will probably result in persecution, but it is enough that persecution is a reasonable possibility" in order to qualify for asylum. ${ }^{87}$ In fact, " $10 \%$ chance of [persecution may be sufficient to establish] well-founded fear.... [I]t is enough that persecution is a reasonable possibility." 88 Clearly, the applicant is not required to prove that it is more likely than not he or she will be persecuted. ${ }^{89}$ The

82. 8 U.S.C. $\S 1225(\mathrm{~b})(1)(A)($ ii) (2014).

83. 8 U.S.C. $\S 1225(\mathrm{~b})(1)(\mathrm{B})(\mathrm{ii})$.

84. See THE LESSON PLAN, supra note 78, at 11 (explaining that the interviewing officer need only find a "credible" fear of persecution to continue the interview process).

85. See id

86. 8 U.S.C. $\S 1101(a)(42)$.

87. Cardoza-Fonseca, 480 U.S. at 440.

88. Id. ("There is simply no room in the United Nations' definition for concluding that because an applicant has only has a $10 \%$ chance of being shot, tortured, or otherwise persecuted, that he or she has no 'well-founded fear'").

89. Prior to Cardoza-Fonseca, the Supreme Court held that the "more likely than not" standard of persecution did apply to the "clear probability" standard for withholding of deportation. INS v. Stevic, 467 U.S. 407, 424 (1984). Cardoza-Fonseca provided the Supreme Court the opportunity to explain for the first time that the well-founded fear standard for asylum was intended to be more generous than the withholding standard. See 480 U.S. at 425-26; the two provisions were located in two different parts of the Immigration and Nationality Act. See id. at 432 (discussing the two standards). 
applicant is not required to establish by a preponderance of the evidence that he or she will not be persecuted. ${ }^{90}$ In fact, the Supreme Court's holding in Cardoza-Fonseca requires a very low standard of proof for asylum. ${ }^{91}$ This makes sense, given the humanitarian purpose of asylum and what is at stake if an incorrect decision denying asylum is made. In essence, the benefit of the doubt is given to the applicant. An "applicant for asylum has established a well-founded fear if he shows that a reasonable person in his circumstances would fear persecution. ${ }^{.92}$

Thus, since we know that the asylum standard is low, requiring only a " $10 \%$ chance" or a "reasonable possibility" of persecution, we know intuitively that the credible fear-screening hurdle must be even lower. Instructions suggesting anything more are therefore incorrect and misguided. Therein lies the problem with the Lesson Plan, whose tenor, format, and content suggests too high a burden for credible fear.

Here are some examples of specific problems with the Lesson Plan: Throughout the text, the Lesson Plan points out that credible fear of persecution means that there is a "significant possibility" that the alien can establish eligibility for asylum. ${ }^{93}$ However, this is done without regular acknowledgement and reminder that establishing eligibility for asylum, i.e., well-founded fear, is a relatively low threshold when compared to other burdens of proof such as preponderance of the evidence or beyond a reasonable doubt. Without that reminder or acknowledgement, the officer is left with the words "significant possibility" which connote a high burden. In fact, it is a burden that could possibly require less than a $10 \%$ likelihood of persecution. ${ }^{94}$

The Lesson Plan contains this guidance: The applicant bears the burden of proof to establish a credible fear of persecution or torture. This means that the applicant must produce sufficiently convincing evidence that establishes the facts of the case, and that those facts must meet the relevant legal standard. ${ }^{95}$

The italicized language suggests an incorrect standard. The language suggests that each and every fact must be established by convincing

\footnotetext{
90. See id. at 431 (stating that the fear must be "well-founded" which could be less than a $50 \%$ chance).

91. Id. (explaining that to be granted asylum, the alien need only meet the definition of a refugee, which requires only a well-founded fear of persecution).

92. See In re Mogharrabi, 19 I. \& N. Dec. 439, 445 (BIA 1987).

93. See The Lesson Plan, supra note 78, at 12.

94. See Cardoza-Fonseca, 480 U.S. at 440 (describing the low threshold for "well-founded" fear).

95. The Lesson Plan, supra note 78, at 12 (emphasis added).
} 
evidence. $^{96}$ That language suggests the inapplicable preponderance standard. ${ }^{97}$ That high standard is not even required for asylum, ${ }^{98}$ so it certainly cannot be the proper standard for credible fear that should be much lower.

Citing INA $\S 208(b)(1)(B)(i i)$, the Lesson Plan says that the applicant's testimony is sufficient only if "credible, is persuasive, and refers to specific facts."

Therefore, the terms 'persuasive' and 'specific facts' must have independent meaning above and beyond the first term 'credible.' An applicant may be credible, but nonetheless fail to satisfy his or her burden to establish the required elements of eligibility. 'Specific facts' are distinct from statements of belief. When assessing the probative value of an applicant's testimony, the asylum officer must distinguish between fact and opinion testimony and determine how much weight to assign to each of the two forms of testimony. ${ }^{100}$

This statement and citation to INA $\S 208(\mathrm{~b})(1)(\mathrm{B})(\mathrm{ii})$ comes under the specific part of the Lesson Plan labeled: "V. BURDEN OF PROOF AND STANDARD OF PROOF FOR CREDIBLE FEAR DETERMINATIONS." 101 This is a serious error. In fact, INA $\S$ 208(b)(1)(B)(ii) falls in the section of the Immigration and Nationality Act that pertains to the burden of proof for asylum, not credible fear. ${ }^{102}$ Thus, the Lesson Plan incorrectly instructs that the same burden of proof for asylum applies to credible fear. The clear and incorrect lesson conveyed to the officer is that the credible fear applicant must meet an eligibility requirement that in fact does not apply. ${ }^{103}$

Recognizing credible fear is not a grant of asylum. ${ }^{104}$ It merely recognizes that the person has shown a significant possibility that that the

\footnotetext{
96. See id. (requiring "sufficiently convincing evidence").

97. See id. (stating that the applicant bears the "burden" and must present "convincing evidence").

98. See Cardoza-Fonseca, 480 U.S. at 440 (discussing the relatively low threshold for establishing "well-founded" fear).

99. THE LESSON PLAN, supra note 78, at 13.

100. See id.

101. See id. at $12-13$.

102. See 8 U.S.C. $\$ 1158(b)(1)(B)(2014)$.

103. See THE LesSON PLAN, supra note 78, at 12, (indicating that the standard of proof for credible fear is discussed below when in reality the lesson plan cites to the standard for asylum).

104. See 8 U.S.C. $\S 1158$ (b)(1)(B)(ii) (requiring applicants for asylum demonstrate credible testimony); see also INS v. Cardoza-Fonseca, 480 U.S. 421, 428 (1987) (explaining how the attorney general first determines whether the alien meets the definition of refugee, demonstrating a "wellfounded" fear, before they may be granted asylum. Thus a well-founded fear is merely the first requirement).
} 
applicant can meet the less-than-preponderance standard for asylum before an immigration judge. ${ }^{105}$ As such, the credible fear standard is quite low. A credible fear finding simply gives the person a chance for a fair hearing in an immigration court. ${ }^{106}$ Credible fear requires less than a one in ten chance that persecution is likely ${ }^{107}$ - something that the new Lesson Plan fails to teach. ${ }^{108}$

Those who come to our borders seeking asylum deserve fair treatment. This administration should not be associated with the tragic asylum eras of the past. ${ }^{109}$ Politics should not get in the way. The entire content of the Lesson Plan should be reconsidered so that asylum seekers are treated fairly at this screening stage. If they meet the correct, contextualized credible fear standard, they should be allowed to make a case for asylum in front of an immigration judge where all the nuances of asylum law can be fairly evaluated. Given the likely manifestations of PTSD, complications in assessing credibility, possible challenges with translation, and other logistical challenges, the screening function of credible fear determinations is most correctly viewed as one of deference to the applicant. The integrity of the asylum system should be protected by suspending the new Lesson Plan and installing one that more accurately reflects the statutory framework as well as the purpose and minimal legal requirements that attach to credible fear determinations.

\section{H. Family Separation}

Felipe Calderon is not unlike many natives of Mexico who are living in the United States without proper documents. ${ }^{110}$ Calderon was born in 1955 in a small town in the state of Guanajuato, Mexico. He grew up poor - often lacking food, clothing, and housing. He attended the local elementary school through the third grade - the highest level of education that the hometown elementary school offered. He then

\footnotetext{
105. See 8 U.S.C. $\S 1158$ (d)(iv)(describing the procedure for considering an asylum application); see also Cardoza-Fonseca, 480 U.S. at 431 ("That the fear must be "well-founded" does not alter the obvious focus on the individual's subjective beliefs, nor does it transform the standard into a 'more likely than not' one.").

106. 8 U.S.C. $\S 1158(d)(5)$ (describing the procedure for considering an asylum application).

107. Cardoza-Fonseca, 480 U.S. at 440.

108. See THE LeSSON Plan, supra note 78, at 13.

109. See, e.g., Orantes-Hernandez v. Thornburgh, 919 F.2d 549 (9th Cir. 1990); Haitian Refugee Center v. Smith, 676 F.2d 1023 (5th Cir. Unit B 1982); American Baptist Churches v. Thornburgh, 760 F.Supp. 796 (N.D. Cal. 1991).

110. Material accompanying footnotes 110 through 111 is Author's analysis of Family Separation as previously published in Bill Ong Hing, The Failure of Prosecutorial Discretion and the Deportation of Oscar Martinez, 15 SCHOLAR: ST. MARY’S L. REV. \& SOC. JUST. 437, 446-49 (2013).
} 
attended three more years of school in a town that was five kilometers away, walking two hours each way because the family could not afford to pay for the van ride. As the oldest child, he had to stop school and begin working by age eleven to help put food on the table.

Mr. Calderon's hometown - Valle de Santiago — only had about five hundred residents, and the only work available was in the agricultural fields. Some years later, his father decided to try his luck in Mexico City to earn more money. Mr. Calderon and two of his brothers, who also left school at an early age to help work, remained in Valle de Santiago to work in the fields. In 1975, the entire family moved to Mexico City to join their father, where Mr. Calderon found work in a stationery store making minimum wage - more than what he made in the fields.

Shortly thereafter, Mr. Calderon met Laura Gomez and fell in love. After three years of dating, they decided to get married and form their own family. Even after marrying, Mr. Calderon still felt he had an obligation to help his parents and siblings with expenses, so he continued to share part of his salary with them. His dream was to build a house with his wife and raise children in an environment where they could obtain a good education - an environment very different from his own childhood. Unfortunately, the couple learned that Laura was unable to have children, but they continued to strive for their dream of earning enough money to build a home. However, good work became difficult to find even though expenses were climbing.

Like so many others, Mr. Calderon looked to the United States to pursue his dream. In 1985, he entered with his father-in-law, looking for work in Oakland, California. He soon found work as a potato packer for a produce company earning only $\$ 120$ per week. Six months later, he found a better job working the graveyard shift from $11 \mathrm{PM}$ to $7 \mathrm{AM}$ in the kitchen of a Holiday Inn (later purchased by Hilton Hotel). Mr. Calderon worked the graveyard shift for ten years. By working hard, $\mathrm{Mr}$. Calderon was given the opportunity to work the day shift, and he maintained that shift until August 2007, when he was arrested by ICE. Although the pay was modest, the job provided medical benefits. In addition to working at the hotel, Mr. Calderon worked part time at a pizza parlor to supplement his income. In total, he averaged sixty-eight to seventy-two hours of work a week to provide for his family's needs. When the Board of Immigration Appeals (BIA) ruled against him in 2010, Mr. Calderon had worked in the hotel kitchen for almost twentyfive years.

After his first trip to the United States, Mr. Calderon returned to Mexico a couple of times. His last entry was in 1987 with his first wife Laura, and he resided in the United States continuously since then. In 
September 1993, they decided to buy a house in Oakland, with the idea that they would adopt a child in the future. Both continued working, but in 1994 Laura began getting sick. Her illness became so debilitating that after a while she had to stop working. Doctors discovered a problem that affected Laura's lungs and heart, which caused her to suffer a great deal. Sadly, Laura died in January 1995.

The loss of Laura changed Mr. Calderon completely. He was alone in the United States. He did not want his parents or siblings to come to the United States because of the difficulties and dangers of crossing the border. This was a painful period for him, having lost his wife of seventeen years. Mr. Calderon took refuge in his work; he also played baseball to take his mind off the tragedy.

After some time, his friends suggested that Mr. Calderon look for a new partner so he would not be alone. He was doubtful that he could find someone who would understand his situation and state of mind. However, a couple he knew told him about another friend whose spouse also had passed away. They told Mr. Calderon about Juana, who was now alone with two young children and also needed companionship. Mr. Calderon was interested in meeting Juana, especially because she had two children.

Mr. Calderon and Juana were introduced and they eventually married in March 1996. He treated Juana's two children Donaldo and Lorena like his own; they were quite young when he became their stepfather. They felt so fortunate to have been brought together when each was in such great pain and need. They truly felt that they were brought together through divine intervention.

Unfortunately, ICE arrested Mr. Calderon while working in the hotel kitchen and placed him in removal proceedings. At his deportation hearing, Mr. Calderon applied for cancellation of removal, and his attorney introduced strong supporting documents from Mr. Calderon's friends and neighbors that describe him as a humble, caring, and wellrespected member of the community.

Mr. Calderon and his second wife successfully integrated into the community and established roots. Mr. Calderon was a good neighbor, a good worker, and a regular churchgoer. He was the godfather to a disabled boy, and participated in church and community events. Reverend A.M., executive director of a local church organizing group, noted that Mr. Calderon and his family "participated in many community activities in our organization.... [W]e [sic] are grateful for their leadership, responsibility, and commitment to the community." 
Mr. Calderon's commitment to the community extended beyond religious boundaries. Mr. L.A., a union representative, wrote that $\mathrm{Mr}$. Calderon "has been an active Union member... for 22 years. He has always helped his co-workers with problems, attended Union meetings, and worked together with management to resolve any issues as they came up." Mr. Calderon also was deeply involved in PTA meetings, school activities, and community athletic and cultural programs. Other parents in the community expressed, "Mr. [Calderon] is an active, honest, respectful, and quietly supportive member of our community soccer programs. He and his wife are truly role models for his children as well as their teammates." Mr. Calderon's service to the community through many outlets has made him a role model for other children and adults. For example, parents in the community have described $\mathrm{Mr}$. Calderon as "a very responsible person, dedicated to the well-being of his family, deeply involved in community and family activities, PTA meetings, school reunions[,] and church issues." The PTA Council President expressed, "I feel strongly that Mr. [Calderon] is a stabilizing factor in our community. We need more men like him, who are loyal and loving to their families."

Another Berkeley parent noted:

[Y]ear after year, [Mr. Calderon] volunteered with me in events held for the local church and Berkeley Unified School District where our children attended. As part of his nature, [Mr. Calderon] goes out of his way to motivate our Latino population and even organizes cultural celebrations at our church and local senior centers.

The evidence was strong enough for the immigration judge to grant Mr. Calderon's application for cancellation, but the government appealed, and the BIA reversed on the grounds that the "Immigration Judge erred in concluding the respondent met his burden in establishing the requisite hardship." The BIA felt that neither U.S. citizen children "suffered from any health issues," or "showed compelling educational needs." Regarding Lorena, the BIA held the possibility that she "may not be able to complete her college education" due to Mr. Calderon's removal did not constitute an "exceptional and extremely unusual hardship." Nor did the evidence regarding Felipe Jr. establish for the BIA that he would "suffer hardship which is substantially beyond what would ordinarily be expected as a result of the respondent's removal."

A month prior to Mr. Calderon's removal, I asked the local ICE director to grant deferred action to Mr. Calderon based on prosecutorial discretion instructions from the ICE director in Washington, D.C. His response was a flat rejection: 
The June 17 and August 18 memos and announcements from D.C. didn't say anything new that I have not already been doing; they didn't change anything; they didn't change my marching orders; 25 years residence doesn't mean anything; [Calderon] just happened to be under the radar. The public expects us to enforce immigration laws. No one has told me the [Calderon] case is a low priority case; resources have always been expended on these kinds of cases. I also won't consider an extension of time for him to attend [Lorena]'s graduation. If I did that, then what about the next kid?

\section{DISRUPTION OF UNFAIR IMMIGRATION ENFORCEMENT}

\section{A. Impact Litigation}

When enforcement of immigration laws results in outcomes that we regard as unfair, inappropriate, or unjust, immigrants and their allies rely on a range of strategies or tools to challenge the results or the processes that lead to those results. Conventionally, those strategies include impact litigation and legislative advocacy. Many examples of those strategies demonstrate disruption of immigration enforcement or unreasonable immigration policies.

Impact litigation examples in the immigrant rights area abound. For example, the Ninth Circuit opinion in Orantes-Hernandez v. Thornburgh reveals that immigration officials engaged in a strategy that foreclosed the opportunity to apply for asylum for Salvadorans during the $1980 \mathrm{~s}^{112}$

Generally, after aliens were apprehended, either border patrol agents or INS officers processed them. ${ }^{113}$ INS processing of detained aliens consisted of an interrogation combined with the completion of various forms, including form I-213, Record of Deportable Alien, and the presentation of form I-274 Request for Voluntary Departure. Although the arrested Salvadorans were eligible to apply for political asylum and to request a deportation hearing prior to their departure from the United States, the vast majority of Salvadorans apprehended signed voluntary departure agreements that commenced a summary removal process. Once a person signed for voluntary departure in the course of INS processing, he or she was subject to removal from the United States as soon as transportation could be arranged. A person given administrative

111. Id

112. 919 F.2d 549, 559 (9th Cir. 1990) (explaining finding of facts which "revealed a pattern and practice of interference and coercion on the part of INS agents which prevented Salvadoran aliens who feared return to their country from exercising their right to apply for asylum").

113. Material accompanying footnotes 113 through 114 is Author's analysis of Impact Litigation as previously published in HING, supra note 15 , at 185-88. 
voluntary departure in this manner never had a deportation hearing, the only forum before which the detained person could seek political asylum and mandatory withholding of deportation at the time.

The Orantes-Hernandez court found that the widespread acceptance of voluntary departure was due in large part to the coercive effects of the practices and procedures employed by INS and the unfamiliarity of most Salvadorans with their rights under United States immigration laws. INS agents directed, intimidated, or coerced Salvadorans in custody, who had no expressed desire to return to El Salvador, to sign form I-274 for voluntary departure. INS agents used a variety of techniques to procure voluntary departure, ranging from subtle persuasion to outright threats and misrepresentations. Many Salvadorans were intimidated or coerced to accept voluntary departure even when they had unequivocally expressed a fear of returning to El Salvador. Even when an individual refused to sign form I-274, "Waiver of Rights," INS officers felt that they could present the person with the voluntary departure form.

The court also found that INS processing officers engaged in a pattern and practice of misrepresenting the meaning of political asylum and of giving improper and incomplete legal advice, which denied arrested Salvadorans meaningful understanding of the options presented and discouraged them from exercising available rights. INS officers and agents routinely advised Salvadorans of the negative aspects of choosing a deportation hearing without informing them of the positive options that were available. Without informing them that voluntary departure could be requested at a deportation hearing, INS officers advised detainees that if they did not sign for voluntary departure they could be formally deported from the United States, and that such a deportation would preclude their legal re-entry without the permission of the Attorney General.

INS officers and agents routinely told Salvadoran detainees that if they applied for asylum they would remain in detention for a long time, without mentioning the possibility of release on bond. Similarly, without advising that an immigration judge could lower the bond amount and that there were bond agencies that could provide assistance, INS agents regularly told detainees that if they did not sign for voluntary departure they would remain detained until bond was posted. Some agents told individuals the monetary bond amount they could expect or the bond amount given to other Salvadorans, without telling them that the bond amount ultimately depended upon the circumstances of the individual.

INS officers commonly told detainees that if they applied for asylum, the application would be denied, or that Salvadorans did not get asylum. INS officers and agents represented that Salvadorans ultimately would be 
deported regardless of the asylum application. INS officers and agents misrepresented the eligibility for asylum by saying that it was only given to guerillas or to soldiers. INS processing agents or officers further discouraged Salvadorans from applying for asylum by telling them that the information on the application would be sent to El Salvador. INS processing officers also used the threat of transfer to remote locations as a means of discouraging detained Salvadorans from exercising their rights to a hearing and to pursuing asylum claims.

Furthermore, INS agents often did not allow Salvadorans to consult with counsel prior to signing the voluntary departure forms, although they acknowledged that aliens had this right. Even those Salvadorans fortunate enough to secure legal representation were often unable to avoid voluntary departure, as INS' practice was to refuse to recognize the authority of counsel until a formal notice of representation (Form G-28) was filed. Due to the rapid processing of Salvadoran detainees, it was often physically impossible for counsel to locate their clients and file Form G-28 before the client was removed from the country. ${ }^{114}$

The Orantes-Hernandez court noted:

The record before this Court establishes that INS engages in a pattern and practice of pressuring or intimidating Salvadorans who remain detained after the issuance of an OSC [Order to Show Cause] to request voluntary departure or voluntary deportation to El Salvador. There is substantial evidence of INS detention officers urging, cajoling, and using friendly persuasion to pressure Salvadorans to recant their requests for a hearing and to return voluntarily to El Salvador.

That this conduct is officially condoned, even in the face of complaints, demonstrates that it is a de facto policy. The existence of a policy of making daily announcements about the availability of voluntary departure, coupled with the acknowledgement that the policy is designed to free-up scarce detention space, supports the conclusion that INS detention officers make a practice of pressuring detained Salvadorans to return to El Salvador. This conduct is not the result of isolated transgressions by a few overzealous officers, but, in fact, is a widespread and pervasive practice akin to a policy.

This pattern of misconduct flows directly from the attitudes and misconceptions of INS officers and their superiors as to the merits of Salvadoran asylum claims and the motives of class members who flee El Salvador and enter this country. ${ }^{115}$

114. $I d$

115. Orantes-Hernandez v. Meese, 685 F.Supp. 1488, 1505 (C.D. Cal 1988), aff'd sub nom. 
Thus, the district court order was affirmed:

1. [INS and border patrol agents] shall not employ threats, misrepresentation, subterfuge or other forms of coercion, or in any other way attempt to persuade or dissuade class members when informing them of the availability of voluntary departure pursuant to 8 U.S.C. § 1252(b). The prohibited acts include, but are not limited to:

(a) Misrepresenting the meaning of political asylum and giving improper and incomplete legal advice to detained class members;

(b) Telling class members that if they apply for asylum they will remain in detention for a long period of time, without mentioning the possibility of release on bond or indicating that bond can be lowered by an immigration judge and that there are bond agencies which can provide assistance;

(c) Telling Salvadoran detainees the amount of bond given to other class members, without indicating that the bond amount ultimately depends upon the circumstances of the individual class member;

(d) Telling class members that their asylum applications will be denied, that Salvadorans do not get asylum, or that asylum is only available to guerillas or soldiers;

(e) Representing to class members that the information on the asylum application will be sent to El Salvador;

(f) Representing to class members that asylum applicants will never be able to return to El Salvador;

(g) Indicating that Salvadoran detainees will be transferred to remote locations if they do not elect voluntary departure;

(h) Advising Salvadorans of the negative aspects of choosing a deportation hearing without informing them of the positive options that are available;

(i) Refusing to allow class members to contact an attorney; and

(j) Making daily announcements at detention facilities of the availability of voluntary departure. ${ }^{11}$

Orantes-Hernandez v. Thornburgh, 919 F.2d 549 (9th Cir. 1990).

116. Id. at 1511 
The bias that INS officials and asylum corps officers exhibited toward both Guatemalan and Salvadoran asylum applicants was further exposed in American Baptist Churches v. Thornburgh. ${ }^{117}$ As the New York Times reported on the case:

Such applications have long presented the Government with an embarrassing choice. The United States supports the Governments of El Salvador and Guatemala, and at the same time it is asked by asylum applicants to find that they have a "well-founded fear of persecution" if they are returned home. Every approval of an application for political asylum thus amounts to an admission that the United States is aiding governments that violate the civil rights of their own citizens.

Since 1980 the Government has denied 97 percent of applications for political asylum by El Salvadorans and 99 percent of those by Guatemalans. During the same time, applications for political asylum by Eastern Europeans, Nicaraguans and residents of other countries have a high percentage of approval. For example, 76 percent of applications by residents of the Soviet Union were approved, as were 64 percent of those by residents of China. ${ }^{118}$

A settlement was reached requiring the INS to readjudicate the asylum claims of certain Salvadorans and Guatemalans who were present in the United States as of 1990, and who had sought immigration benefits. ${ }^{119}$ The case, known as the "ABC litigation" began in 1985 as a nationwide class action on behalf of Salvadorans and Guatemalans. ${ }^{120}$ The plaintiffs alleged that the INS and the Executive Office of Immigration Review were biased in their asylum adjudication process for those two nationalities. ${ }^{121}$ Under the settlement, these Central Americans were eligible for new asylum interviews. ${ }^{122}$

In Haitian Refugee Center v. Smith, ${ }^{123}$ the Fifth Circuit chastised the federal government for unfair processes that were imposed on Haitian asylum applicants. ${ }^{124}$ In response to the repressive Duvalier regime that caused political and economic havoc in Haiti in the 1970s, many Haitians

117. 760 F.Supp. 796 (N.D. Cal. 1991).

118. Katherine Bishop, U.S. Adopts New Policy for Hearings On Political Asylum for Some Aliens, N.Y. TIMES (Dec. 20, 1990), http://www.nytimes.com/1990/12/20/us/us-adopts-new-policyfor-hearings-on-political-asylum-for-some-aliens.html.

119. American Baptist Churches v. Thornburgh, 760 F. Supp. 796, 810 (N.D. Cal. 1991).

120. See id. at 799 .

121. See id.

122. See id.

123. 676 F.2d 1023 (5th Cir. 1982).

124. Id. at $1031-32$. 
fled to the United States seeking refuge. ${ }^{125}$ Large numbers sought asylum once they reached the shores of Florida. ${ }^{126}$ A backlog developed, so INS officials implemented an accelerated program to deal with the situation. ${ }^{127}$

The program of accelerated processing to which the [Haitians were] subjected by the INS-termed the "Haitian Program"- embodied the government's response to the tremendous backlog of Haitian deportation cases that had accumulated in the INS Miami district office by the summer of 1978. ${ }^{128}$ By June of that year between six and seven thousand unprocessed Haitian deportation cases were pending in the Miami office. These staggering numbers were not the result of a massive influx of Haitians to south Florida over a short period. Although significant numbers of Haitians had entered the United States from Haiti and the Bahamas in the spring of 1978, the backlog was primarily attributable to a slow trickle of Haitians over a ten-year period and to the confessed inaction of the INS in dealing with these aliens.

Many officials provided input in the planning process of the Haitian project. Assigned by [the Deputy Commissioner of the INS] with the task of assessing the Haitian situation in Miami, INS Regional Commissioner Armand J. Salturelli submitted the recommendation, among others, that processing could be expedited by ceasing the practice of suspending deportation hearings upon the making of an asylum claim. Salturelli acknowledged that this would contravene internal operations procedures, but suggested that those procedures should be cancelled or "at least be suspended insofar as Haitians are concerned." One July 1978 report from the Intelligence Division of INS to the Associate Director of Enforcement advised in absolute terms that the Haitians were 'economic' and not political refugees and, in belated recognition of the obvious, warned the Enforcement Division that favorable treatment of these Haitians would encourage further immigration. Associate Director of Enforcement, Charles Sava, later visited Miami to find space for holding an increased number of deportation hearings and to discuss with Miami personnel the processing of Haitians. Out of those discussions arose

125. Id. at 1042 ("It is beyond dispute that some Haitians will be subjected to the brutal treatment and bloody prisons of Francois Duvalier upon their deportation" (internal citations omitted)).

126. Id. at 1026 (“. . filed a class action in federal district court on behalf of over 4,000 Haitians in the south Florida area who had sought political asylum in the United States").

127. Id. at 1029 .

128. Material accompanying footnotes 150 through 151 was previously included in Letter from Bill Ong Hing, Professor Univ. San Francisco School of Law, to President Barack Obama (Nov. 4, 2013) (on file with Author). 
recommended deterrence measures, which Sava outlined in a letter to Deputy Commissioner Noto. These included "detention of arriving Haitians likely to abscond, blanket denials of work permits for Haitians, swift expulsion of Haitians from the United States, and enforcement actions against smugglers.

Planning of the Haitian program culminated in a memorandum sent on August 20, 1978 by Deputy Commissioner Noto to INS Commissioner Leonel J. Castillo. The memo explained the basic mechanics of the accelerated processing already being implemented in the Miami district office. Among the specifics set forth were the assignment of additional immigration judges to Miami, the instructions to immigration judges to effect a three-fold increase in productivity, and orders for the blanket issuance of show cause orders in all pending Haitian deportation cases.

In accordance with the goal of high productivity demanded of the Miami office, [Acting District Director] Gullage issued a memorandum to all personnel in the office, stating 'processing of these cases cannot be delayed in any manner or in any way. All supervisory personnel are hereby ordered to take whatever action they deem necessary to keep these cases moving through the system."' The Haitian cases were processed at an unprecedented rate." Prior to the Haitian program only between one and ten deportation hearings were conducted each day. During the program, immigration judges held fifty-five hearings per day, or approximately eighteen per judge; at the program's peak the schedule of deportation hearings increased to as many as eighty per day.

At the show cause or deportation hearing, the immigration judges refused to suspend the hearing when an asylum claim was advanced, requiring the Haitians instead to respond to the pleadings in the show cause order and proceed to a finding of deportability. The order entered by the judge allowed the Haitian ten days for filing an asylum claim with the district director, then ten days to request withholding of deportation from the immigration judge if the asylum deadline was not met. Failure to seek withholding in a timely manner effected automatic entry of a deportation order.

Deportation hearings were not the only matter handled during the Haitian program. Asylum interviews also were scheduled at the rate of forty per day. Immigration officers who formerly had worked at the airport were enlisted as hearing officers for these interviews. Prior to the program such interviews had lasted an hour and a half; during the program the officer devoted approximately one-half hour to each Haitian. In light of the time-consuming process of communication through interpreters, the court concluded that only fifteen minutes of substantive 
dialogue took place. Consistent with the result-oriented program designed to achieve numerical goals in processing, the Travel Control section in the Miami office recorded the daily totals of asylum applications processed. The tally sheet contained space only for the total number of denials; there was no column for recording grants of asylum.

Hearings on requests for withholding deportation also were being conducted simultaneously with asylum and deportation hearings, at several different locations. It was not unusual for an attorney representing Haitians to have three hearings at the same hour in different buildings; this kind of scheduling conflict was a daily occurrence for attorneys throughout the Haitian program. The INS was fully aware that only approximately twelve attorneys were available to represent the thousands of Haitians being processed, and that scheduling made it impossible for counsel to attend the hearings. It anticipated the scheduling conflicts that in fact occurred. Nevertheless the INS decided that resolving the conflicts was 'too cumbersome for us to handle' and adopted the attitude that everything would simply work out.

Under these circumstances, the court concluded that the INS had knowingly made it impossible for Haitians and their attorneys to prepare and file asylum applications in a timely manner. The court found that adequate preparation of an asylum application required between ten and forty hours of an attorney's time. The court further estimated that if each of the attorneys available to represent the Haitians "did nothing during a 40 hour week except prepare [asylum applications], they would have been able to devote only about 2 hours to each client."

The results of the accelerated program adopted by INS are revealing. None of the over 4,000 Haitians processed during this program were granted asylum. ${ }^{129}$

In the end, the federal court of appeals struck down the accelerated program as a violation of procedural due process. ${ }^{130}$ The government was forced to submit a procedurally fair plan for the orderly reprocessing of the asylum applications of the Haitian applicants who had not been deported. ${ }^{131}$

More recently, litigation challenging the conditions at the Artesia facility contributed to its closure. Of course, pro bono work at the Artesia facility by volunteer attorneys contributed pressure to close the

129. Id

130. Haitian Refugee Center v. Smith, 676 F.2d 1023, 1040 (5th Cir. 1982).

131. Id. at 1041 . 
facility as well. ${ }^{132}$ They filed affidavits in support of the lawsuit that highlighted both the harsh conditions as well as the fact that through competent representation, the majority of UACs are eligible for relief. ${ }^{133}$

\section{B. Non-Litigation Disruptions}

\section{Legal Services and Pro Bono Advocates}

The critical role that legal services programs play in representing immigrants in day-to-day cases is well known. A program such as Dolores Street Community Services in San Francisco takes on difficult asylum cases and criminal immigration deportation defense matters. ${ }^{134}$ The Florence Immigrant and Refugee Rights Project provides much needed representation to thousands of immigrants each year held in detention centers in a rural part of Arizona. ${ }^{135}$ The Immigration Project in Chicago provides a range of visa and deportation defense services to immigrants from around the world. ${ }^{136}$ The same is true for wellestablished organizations across the country. And their services make a huge difference, serving as a constant disruption to the over-zealous immigration enforcement ICE machine. ${ }^{137}$

This important legal services disruption in the immigration area also is epitomized by tremendous pro bono efforts by the private bar. Consider one recent pro bono effort responding to the unaccompanied alien children border crisis.

For its feature article "Adult Asylum-Seekers Need Lawyers, Too," The National Law Journal profiled the work of Akin Gump first-year associate Lauren Connell, whom the firm seconded to its San Antonio office to work full time with undocumented Central American women

132. Esther Yu-Hsi Lee, Lawyers Say Detention Center Designed To Quash Legitimate Asylum Claims, ThINK PRogress (Aug. 27, 2014, 9:00 AM), http://www.thinkprogress.org/ immigration/2014/08/27/3475472/lawsuit-artesia-detention-center/.

133. Id.

134. See Dolores Street Community Services, http://www.dscs.org/ (last visited May 25, 2015).

135. See The Florence Immigrant and Refugee Rights Project, http://www.firrp.org/ (last visited May 25, 2015).

136. See The Immigration ProjeCt, http://www.immigrationproject.org/ (last visited May 25, 2015).

137. “A study by Syracuse University's Transactional Records Access Clearinghouse Immigration Project found that roughly 90 percent of children facing deportation proceedings without a lawyer got deported, compared with about 50 percent for those who had legal representation." Roque Planas, New York To Pay For Legal Aid For Kids Facing Deportation, HUFFINGTON POST (Sept. 23, 2014, 6:02 PM), http://www.huffingtonpost.com/2014/09/23/newyork-to-pay-for-lawye_n_5870492.html. 
and children seeking asylum and being held at the Department of Homeland Security's Karnes City, Texas, detention center.

In late August [2014, the national law firm,] Akin Gump[,] formed the Karnes City Immigrant Family Pro Bono Project with representatives from the University of Texas Law School Immigration Clinic, the Tahirih Justice Center in Houston, the American Immigration Lawyers Association in Austin and Human Rights First in Houston. ${ }^{138}$

The project was a critical response to the Obama administration's incarceration of unaccompanied children and children coming with mothers from Central America seeking asylum and being held at the Department of Homeland Security's Karnes City, Texas, detention center. ${ }^{139}$ "[T]he Karnes City Residential Center... holds 170 to 200 female detainees in various early stages of the asylum process who face deportation. ... [M] ore than [twenty] Akin Gump attorneys [] coordinate legal assistance for these women and their children," and the firm has trained dozens of other pro bono attorneys who travel to Karnes from across the country. ${ }^{140}$

Steven Schulman, Akin Gump's pro bono partner, is on the project's advisory committee. [He was struck by how] many of the women whom the firm is assisting are victims of abuse and sexual assault seeking asylum as a way to escape from the violence they face in their home countries. ... [T] he brevity of the asylum screening interview, done via a translator, means that many women can't express their fears well enough by interview's end, saying, "That's why we were called in, [to] see whether we could get lawyers down there to throw sand into the gears. We weren't trying to break a system, but we were trying to slow it down."141

\section{Immigrant Disruptions}

During his campaign for the presidency in 2008, Barack Obama pledged to push for comprehensive immigration reform within the first year of his administration. ${ }^{142}$ However, as the President spent most of his

\footnotetext{
138. NLJ Features Akin Gump Lawyers, Pro Bono Program for Asylum Seekers in Texas, AKIN GuMP (Oct. 13, 2014), http://www.akingump.com/en/news-publications/nlj-features-akin-gumplawyers-pro-bono-program-for-asylum.html.

139. See id.

140. Id

141. Id

142. Lucia Graves \& Elise Foley, Immigration Advocates Push Obama To Make Good On Campaign Promises, HufFINGTON POST (Mar. 31, 2011, 5:26 PM), http://www.huffingto npost.com/2011/03/31/immigration-obama-campaign-promises_n_843285.html.
} 
first year dealing with the financial crisis, his primary legislative efforts were focused on health care reform, and the Affordable Care Act was not signed until March 23, 2010. ${ }^{143}$ At that point, the President and democratic congressional leaders, who controlled both houses at the time tried unsuccessfully to pass a comprehensive immigration bill. ${ }^{144}$

With the chance of comprehensive reform fading in 2010, DREAMers urged congressional leaders at the very least to pass the DREAM Act. The House of Representatives passed the bill on December 8,2010 by a vote of 216 to $198 .{ }^{145}$ However, a few days later, the Senate only came up with 55 votes to bypass a filibuster of the DREAM Act-five votes short of the sixty needed to bring the legislation to an actual up or down vote. ${ }^{146}$

Disappointed, DREAMers and immigrant rights advocates continued their well-documented campaign of protests. For example, on June 27, 2011, six DREAMers were arrested in Atlanta, Georgia, for blocking an intersection in front of the state capitol. ${ }^{147}$ Nataly Ibarra, a 16-year-old high school student, stated: "It's time to stand up and let the world know that we need to fight for what we believe in."148 A month later, about twenty DREAMers interrupted a speech by President Obama at a conference in Washington, D.C. One DREAMer from Florida, Felipe Matos, explained: "We stood up while President Obama gave another of his predictable speeches on immigration because we are outraged at his trying to promote his election among Latinos while continuing to deport us at a time when there is no legislative solution to the immigration crisis." 149 The protestors wore shirts that read: "Obama Deports DREAMers." 150 During the 2012 presidential campaign, two dozen DREAMers staged a sit-in at Obama campaign headquarters in Denver in

143. Patient Protection and Affordable Care Act of 2010, 42 U.S.C. § 18001 (Supp. 2014).

144. Rachel Weiner, How Immigration Reform Failed, Over and Over, WASH. Post (Jan. 30, 2013), http://www.washingtonpost.com/blogs/the-fix/wp/2013/01/30/how-immigration-reformfailed-over-and-over/.

145. Elise Foley, DREAM Act Passes The House, Huffington Post (Dec. 8, 2010, 10:35 PM), http://www.huffingtonpost.com/2010/12/08/dream-act-passes-house_n_794181.html.

146. Elise Foley, DREAM Act Vote Fails In Senate, HufFIngTon Post (Dec. 18, 2010, 11:31 AM), http://www.huffingtonpost.com/2010/12/18/dream-act-vote-senate_n_798631.html.

147. Kate Brumback, Georgia Immigration Law: 6 Illegal Immigrants Arrested During Protest, HufFINGTON POST (June 28, 2011, 11:54 PM), http://www.huffingtonpost.com/2011/06/28/georgiaimmigration-law-illegal-immigrants-arrested_n_886622.html.

148. Id.

149. Latino Youth Interrupt President Obama Speech to Protest His One Million Deportations, Including Many DREAMers, FACEBOOK (July 25, 2011, 10:23 AM), https://www.facebook. $\mathrm{com} /$ notes/presenteorg/latino-youth-interrupt-president-obama-speech-to-protest-his-one-milliondeporta/10150329833808623.

150. Id. 
early June. ${ }^{151}$ They demanded an executive order ending the deportation of DREAMers. ${ }^{152}$ That spring, their presence was so strong, that even Republican Senator Marco Rubio requested a meeting with Gaby Pacheco, a DREAM leader, to discuss how to get the DREAM Act passed. ${ }^{153}$ Rubio considered introducing his own version of the DREAM Act. ${ }^{154}$

The DREAMer disruption yielded results. On June 15, 2012, President Obama announced that he would exercise prosecutorial discretion and not deport DREAMers who had entered the United States prior to the age of $16 .^{155}$ They also would be granted work permits for two years with an opportunity to renew. ${ }^{156}$ This was an amazing discretionary act that could benefit 800,000 individuals. ${ }^{157}$

While President Obama's action on behalf of DREAMers was consistent with the immigration agency's traditional prosecutorial discretion to grant deferred action to sympathetic, albeit, deportable immigrants, ${ }^{158}$ the scope was unprecedented. Republican critics argued

151. John Ingold, Immigration activists stage sit-in at Denver Obama office, DENVER POST (June 5, 2012, 9:47 PM), http://www.denverpost.com/ci_20791243/immigration-activists-stage-sitat-denver-obama-office.

152. Id.

153. Julianne Hing, Marco Rubio Meets with Latino Dems, DREAMers on Alternative Youth Immigration Bill, COLORLINES (Apr. 26, 2012, 2:05 PM), http://www.colorlines.com /archives/2012/04/marco_rubio_meets_with_latino_dems_dreamers_on_alternative_youth_immigrat ion_bill.html.

154. Lauren Fox, Rubio's DREAM Act Gamble; Just in Time For The 2012 Election, U.S. NEws (June 12, 2012, 5:31 PM), http://www.usnews.com/news/articles/2012/06/12/rubios-dream-actgamble-just-in-time-for-the-2012-election.

155. Julia Preston \& John H. Chushman Jr., Obama to Permit Young Migrants to Remain in U.S., N.Y. TIMES (June 15, 2012), http://www.nytimes.com/2012/06/16/us/us-to-stop-deportingsome-illegal-immigrants.html?pagewanted=all. A year earlier, director of ICE John Morton issued a prosecutorial discretion memo that in part was intended to ease up on the deportation of DREAMers. Memorandum from John Morton, Dir., ICE, on Prosecutorial Discretion: Certain Victims, Witnesses and Plaintiffs, to All Field Office Dirs., All Special Agents in Charge, and All Chief Counsel (June 17, 2011), available at http://www.ice.gov/doclib/secure-communities/pdf/domestic-violence.pdf. In fact, prosecutorial discretion as outlined by the Morton memo apparently was used on occasion to prevent the deportation of DREAMers. See, e.g., Jessica Coscia, Arrested DREAMers Won't Be Deported, Authorities Say, Fox NEws LAtino (Sept. 8, 2011), http://www.latino. foxnews.com/latino/politics/2011/09/08/dreamers-released-after-arrest-at-immigration-protest-

officials-say-wont-face/. But the inconsistent application of the Morton memo across the country prompted the president to be more specific about protecting DREAMers from deportation in the DACA order to ICE employees.

156. Preston \& Chushman, supra note 155.

157. Id.

158. See Leon Wildes, The Nonpriority Program of the Immigration and Naturalization Service Goes Public: The Litigative Use of the Freedom of Information Act, 14 SAN DIEGO L. REV. 42, 44, 55-58 (1976); HiNG, supra note 15, at 226-28. See generally, Shoba Sivaprasad Wadhia, The Role of Prosecutorial Discretion in Immigration Law, 9 ConN. PUB. INT. L.J. 243 (2010); Michael A. Olivas, Dreams Deferred: Deferred Action, Prosecutorial Discretion, and the Vexing Case(s) of 
that he went beyond the scope of his authority. ${ }^{159}$ And the president himself, only a year earlier, denied that he could "just suspend deportations [of DREAMers] through executive order." 160

As 2010 drew to a close and the DREAM Act failed in the Senate, prospects for comprehensive immigration reform further dimmed as Republicans took control of the House of Representatives. ${ }^{161}$ Serious bipartisan immigration legislation was not considered until after the 2012 presidential elections. With the reelection of Barack Obama, many in the Republican Party sensed that if they were ever to retake the White House, Latino votes would be necessary, and passing comprehensive immigration reform was a prerequisite. ${ }^{162}$

With much fanfare and relative swiftness, on June 27, 2013, the Senate passed a comprehensive bill that was hammered out by four Democrats and four Republicans. ${ }^{163}$ The bill was attacked by the right as providing amnesty for lawbreakers and by the left for being too strict on enforcement and providing an unreasonably long path to citizenship. ${ }^{164}$ But the Republican-controlled House never permitted an up or down vote on the Senate bill, casting aside any concern over appeasing Latino voters. ${ }^{165}$ Thus, efforts at comprehensive immigration reform failed again in 2013 and 2014, as it had in 2010.

While congressional efforts over immigration reform ebbed and flowed in 2013 and 2014, the ICE enforcement machine did not ease up. Although the Deferred Action for Childhood Arrivals (DACA) program for DREAMers was in full swing and about 500,000 DREAMers benefited, Obama's ICE deportations continued at record pace. ${ }^{166}$

DREAM Act Students, 21 WM. \& MARY BILl OF RTS. J. 463 (2012).

159. Preston \& Chushman, supra note 155.

160. Glenn Kessler, Obama's Royal Flip-Flop on Using Executive Action on Illegal Immigration, WASHINGTON POST (Nov. 18, 2014), http://www.washingtonpost.com/blogs/factchecker/wp/2014/11/18/obamas-flip-flop-on-using-executive-action-on-illegal-immigration/.

161. Devin Dwyer, Republicans Win Control of House With Historic Gains, ABC NEWs (Nov. 2, 2010), http://www.abcnews.go.com/Politics/republicans-win-control-house-abc-news-projectsvote-2010-election-results/story?id=12035796.

162. Julia Preston, Latino Groups Warn Congress to Fix Immigration, or Else, N.Y. TIMES (Dec. 12, 2012, 4:12 PM), http:/www.thecaucus.blogs.nytimes.com/2012/12/12/latino-groups-warncongress-to-fix-immigration-or-else/.

163. Alan Silverleib, Senate Passes Sweeping Immigration Bill, CNN (June 28, 2013, 6:45 AM), http:/www.cnn.com/2013/06/27/politics/immigration/.

164. Id.

165. Stoyan Zaimov, Obama: I Will Fight For Immigration Reform Alone Since House Republicans Refuse to Vote, CHRISTIAN POST (July 1, 2014, 9:17 AM), http://www.christianpost. $\mathrm{com} /$ news/obama-i-will-fight-for-immigration-reform-alone-since-house-republicans-refuse-to-vote$122524 /$.

166. William Selway \& Margaret Newkirk, Congress's Illegal-Immigration Detention Quota 
Families continued to be separated as immigrant workers and parents of citizens and DACA recipients were removed. ${ }^{167}$ Enforcement was so intense, that President Obama was dubbed the "deporter-in-chief" by immigrants, their allies, and even the news media. ${ }^{168}$ The image has been exacerbated by the fact that Congress inserted into Homeland Security's 2009 spending bill a requirement that ICE keep a minimum of 33,400 undocumented immigrants locked up at all times (rounded up to 34,000 in 2011). ${ }^{169}$ Private prison companies make close to $\$ 500$ million each year for this ICE "bed mandate.",

Thus, in spite of the implementation of DACA for DREAMers, the president came under fierce criticism for record deportations. Congressman Luis Gutierrez and the University of Arizona estimated that as many as 90,000 to 100,000 undocumented parents were separated from their U.S. citizen children each year. ${ }^{171}$ Immigrant rights advocates argued that the Obama administration is only "paying lip service to a different strategy" and that the detention of criminal and noncriminal immigrants under the Bush and Obama administrations are essentially the same. ${ }^{172}$

With no realistic hope for comprehensive immigration legislation, critics of the continuing deportations demanded that the president act administratively to defer the deportation of anyone who would have been granted protection under the Senate bill that had been passed in $2013 .{ }^{173}$

Costs $\$ 2$ Billion a Year, BloOMBeRg BusinesSweEK (Sept. 26, 2013), http://www.bloomberg.com/ bw/articles/2013-09-26/congresss-illegal-immigration-detention-quota-costs-2-billion-a-year.

167. Michael Alison Chandler, Deportations of Parents Can Cast the Lives of U.S.-Citizen Kids into Turmoil, WASH. POST (Dec. 29, 2013), http://www.washingtonpost.com/local/education/ deportations-of-parents-can-cast-the-lives-of-us-citizen-kids-into-turmoil/2013/12/29/abdf23aa-

6b4c-11e3-b405-7e360f7e9fd2_story.html; Griselda Nevarez, Dreamers Question How Many Parents of Dreamers Have Been Deported, VOXXI (Dec. 20, 2012), http://www.voxxi. com/2012/12/20/dreamers-parents-of-dreamers-deported/.

168. Rebecca Kaplan, Obama is "Deporter-in-Chief," Says Prominent Latino group, CBS NEws (Mar. 4, 2014, 12:47 PM), http://www.cbsnews.com/news/obama-is-deporter-in-chief-saysprominent-latino-group/.

169. Selway \& Newkirk, supra note 166.

170. Id.

171. Victor Medina, Aggressive Deportation Tactics Continue to Separate American Families, EXAMINER.COM (June 3, 2013, 2:04 PM), http://www.examiner.com/article/aggressive-deportationtactics-continue-to-separate-american-families; see also AJ Vicens, The Obama Administration's 2 Million Deportations, Explained, Mother JONES (Apr. 4, 2014, 6:00 AM), http://www.mother jones.com/politics/2014/04/obama-administration-record-deportations.

172. Alfonso Chardy, Noncriminal, Undocumented Immigrants Aren't Being Left Alone, Activists Complain, Miami HeRALD (June 21, 2010), http://www.articles.sun-sentinel.com/2010-0621/news/fl-detained-immigrants-enforcement-20100621_1_criminal-deportations-immigrants-insouth-florida-homeland-security.

173. See Plea to End Deportations Heard Nationwide as Activist Interrupts Obama Speech on Immigration, DEMOCRACY NOw! (Nov. 27, 2013), http://www.democracynow.org/2013/11/2 
In one well-publicized exchange, DACA recipient Ju Hong interrupted the president's speech, exclaiming: "[O]ur families are separated. . . Mr. President, please use your executive order to halt deportations for all 11.5 [million] undocumented immigrants in this country right now."174 The President responded: "[I]f in fact I could solve all these problems without passing laws in Congress, then I would do so. But we're also a nation of laws. That's part of our tradition. And so, the easy way out is to try to yell and pretend like I can do something by violating our laws." 175

In spite of the President's remarks suggesting that he could not act administratively - just as he had previously denied that he could act specifically on protecting DREAMERs, ${ }^{176}$ on November 20, 2014, the President took executive action to block the deportation of four to five million more undocumented immigrants, primarily the parents of U.S. citizen children or lawful permanent resident children. ${ }^{177}$ His announcement even included the intent to end the Secure Communities program. ${ }^{178}$ This was another bold action by the president of unprecedented scope-even broader than the action on behalf of DREAMers. On cue, Republicans claimed that the President acted unconstitutionally, ${ }^{179}$ and legal challenges were filed. ${ }^{180}$ And the immigrant rights community complained that parents of DREAMers were not included in the order. ${ }^{181}$ In the meantime, the White House and community based organizations were preparing for the implementation of the new program. ${ }^{182}$

\footnotetext{
7/my_family_has_been_separated_for (documenting a transcript of the speech).

174. Id.

175. Id.

176. See Wildes, supra note 158.

177. Elise Foley, Obama Moves To Protect Millions From Deportation, Huffington Post (Nov. 20, 2014, 5:59 PM), http://www.huffingtonpost.com/2014/11/20/obama-immigrationplan_n_6178774.html.

178. Obama was Wise to End Secure Communities program, SFGATE (Nov. 28, 2014, 3:00 PM), http://www.sfgate.com/opinion/editorials/article/Obama-was-wise-to-end-Secure-Communities -program-5923254.php.

179. Julia Preston, House Republicans and White House Clash on Obama Immigration Plan, N.Y. TiMES (Dec. 2, 2014), http://www.nytimes.com/2014/12/03/us/politics/jeh-johnson-testifiesbefore-house-homeland-security-committee.html?_r=0.

180. David Montgomery \& Julia Preston, 17 States Suing on Immigration, N.Y. TIMES (Dec. 3 , 2014), http://www.nytimes.com/2014/12/04/us/executive-action-on-immigration-prompts-texas-tosue.html.

181. Amanda Sakuma, Obama Explains Why DREAMers' Parents Were Left Out of Exec Action, MSNBC (Dec. 9, 2014, 6:57 PM), http://www.msnbc.com/jose-diaz-balart/obama-explainswhy-dreamers-parents-were-left-out-exec-action.

182. Winnie Hu, New York Immigration Groups Prepare to Meet Demands of New Policy, N.Y. TIMES (Nov. 28, 2014), http://www.nytimes.com/2014/11/29/nyregion/new-york-agencies-gear-up-
} 


\section{Executive Disruption}

I have been intrigued by the use of the term "disruptive" in the business pages as of late. A disruptive technology is one that displaces an established technology and shakes up the industry or is a groundbreaking product that creates a completely new industry. For example, an October 2014 article in Forbes, Ten Companies That Are Disrupting Their Industries Through Technology, noted:

Looking for a competitive advantage? Try crushing the competition by becoming a leader in your category. How can you do that? By changing the rules of the game. By reinventing the way business is done in your industry. And by using technology to scale quickly, forcing your competition to play catch-up.

Following are ten companies that have done all of the above. Can you find in their stories best practices that will help you disrupt your industry and become a market leader? ${ }^{183}$

Thus, a disruptive innovation is one that helps create a new market and value network, and eventually disrupts an existing market and value network (over a few years or decades), displacing an earlier technology. ${ }^{184}$ The term is used in business and technology literature to describe innovations that improve a product or service in ways that the market does not expect, typically first by designing for a different set of consumers in a new market and later by lowering prices in the existing market. ${ }^{185}$ The term "disruptive technology" has been widely used as a synonym of "disruptive innovation," but the latter is now preferred, because market disruption has been found to be a function usually not of technology itself but rather of its changing application. ${ }^{186}$

Thus, the protests of immigrants, such as DREAMers, and their supporters disrupting and challenging the immigration enforcement regime are important. Their actions - conventional in the sense that sitins, protests, and media campaigns are part of the American call for

to-meet-demands-of-new-immigration-policy.html.

183. Larry Myler, Ten Companies That Are Disrupting Their Industries Through Technology, FORBES (Oct. 3, 2014, 4:40 PM) (emphasis added), http://www.forbes.com/sites/larrymyler /2014/10/03/ten-companies-that-are-disrupting-their-industries-through-technology/.

184. Disruptive Innovation, INNOVATION ZEN, http://innovationzen.com/blog/2006/10/04/ disruptive-innovation/ (last visited May 25, 2015).

185. Disruptive Innovation, ClAYTON CHRISTENSEN, http://www.claytonchristensen.com/keyconcepts/ (last visited May 25, 2015)

186. Id.; see also Disruptive Technology, WHATIs, http://www.whatis.techtarget.com/definition/ disruptive-technology (last visited May 25, 2015). 
social change - have led to changes in immigration enforcement, but are not themselves the disruptive innovation in immigration enforcement. But the results of these actions have led to disruptive innovation in immigration enforcement, namely, President Obama's executive actions which have led to the disruption of the conventional rules of enforcement, thereby forcing ICE officers to defer action against large classes of removable individuals for policy reasons. In other words, the conventional enforcement lens of whether or not the person is removable is forced to give way to a more nuanced lens of giving deference to removable individuals who meet certain criteria. That is disruptive innovation that disrupts the way we look at enforcement-internally and externally.

\section{Human Rights Disruption}

Viewing immigration enforcement through a comparative lens reveals that disruptive innovation of immigration enforcement already has occurred in the European Union (EU). For example, by adopting a Human Rights Convention with strong commitments to maintaining family ties, the idea of simply deporting someone who is undocumented or who has committed a crime has been disrupted; much more than improper papers or a criminal conviction must be considered before a person is deported. In the EU, someone facing deportation essentially can argue that the punishment of deportation must fit the crime and the effect of deportation on the person and his or her family must be given great weight. ${ }^{187}$

The idea that the punishment must fit the crime often is stated in legal terms as lacking in "proportionality," related to notions of due process or the prohibition against cruel and unusual punishment when the punishment is too severe. ${ }^{188}$ In the deportation context, a strong case has been made that the sanction of removal may very well be impermissibly disproportional to the criminal behavior that makes a person deportable. ${ }^{189}$ For example, Angela Banks has reasoned that since deportation can be punitive:

187. See, e.g., Nasri v. France, 21 Eur. Ct. H.R. 458 (1996); AR (Pakistan) v. Secretary of State for the Home Department, [2010] EWCA (Civ) 816, 2010 WL 2754134 (Eng.).

188. Angela M. Banks, Problems, Possibilities and Pragmatic Solutions: Proportional Deportation, 55 Wayne L. ReV. 1651, 1667-68, 1671 (2009); Michael J. Wishnie, Proportionality: The Struggle for Balance in U.S. Immigration Policy, 72 U. PITT. L. REV. 431, 447 (2011).

189. See Banks, supra note 188, at 1666-71. 
The [Supreme] Court's conclusion that the Due Process Clause prohibits punishment that is "greater than reasonably necessary to punish and deter" is an important development for deportation. It opens the door for new conversations about the scope of the state's power to deport noncitizens. This jurisprudence suggests that deportation decisions, like punitive damage awards, must be proportional and that excessive or disproportionate deportation orders exceed the authority of the state to regulate immigration. ${ }^{190}$

The use of a proportionality lens in assessing the propriety of deportation is common in European tribunals. For example, in Nasri v. France, ${ }^{191}$ the European Court of Human Rights blocked the deportation of a 35-year-old Algerian national who had several convictionsincluding theft, assault, and participation in a gang rape:

[R]emoving the applicant from his family and sending him to a country with which he has no ties would expose him to suffering of such gravity that to do so might be regarded as inhuman treatment. In a democratic society which adheres to the principle of respect for the dignify of the human person, a measure of such severity cannot be proportionate to the legitimate aim of maintaining public order. ${ }^{192}$

The European Commission of Human Rights agreed to review Nasri's case on proportionality grounds and considered several psychological evaluations, the possibility that he would be tortured back in Algeria, and the fact that his "family relationships would be made impossible" if he were deported. After considering these factors, the commission concluded that Nasri's deportation was disproportionate and could not be justified. ${ }^{193}$

In AR (Pakistan) v. Secretary of State for the Home Department, ${ }^{194}$ the deportation of an asylum applicant who had been granted indefinite permission to remain in the United Kingdom was upheld, but not until the applicant had been given two warnings following several criminal convictions and unsuccessful participation in drug rehabilitation programs. ${ }^{195}$ The question in the words of the Court of Appeal in the United Kingdom in these cases is "whether deportation is proportionate,

190. Id. at 1669; see also Wishnie, supra note 188, at 457 (arguing that the additional punishments of deportation and exile for lawful permanent residents convicted of aggravated felonies, "may contravene the due process requirement of proportionality.").

191. Nasri v. France, 21 Eur. Ct. H.R. 458 (1996).

192. Id. at 470. (emphasis added).

193. Id. at $466-70$.

194. [2010] EWCA (Civ) 816, 2010 WL 2754134 (Eng.)

195. Id 
giving due weight to the public interest and to the right to family life."196 And the "task of deciding whether deportation is or is not proportionate typically involves weighing up conflicting factors." 197

In deciding that the deportation was not disproportionate, the Court of Appeal considered the criminal record and the warnings that had been issued. But the court also paid close attention to the fact that the applicant had children. The applicant and his wife had divorced, and their three children lived with their maternal grandparents. ${ }^{198}$ As in the Nasri case, the court was well aware of the fundamental right to family life protected by Article 8 of the European Convention on Human Rights. ${ }^{199}$ However, the court was influenced by the fact that the applicant's earlier close contact with his children was no longer the pattern - in part because of his intermittent time in prison - and therefore was insufficient "to outweigh the public interest in his deportation." 200

In a much broader way, the EU has disrupted the notion of immigration enforcement by the elimination of borders between member states. Under the current structure of the EU, workers who are citizens of different states may freely migrate to other states. ${ }^{201}$ Unlike the North American Free Trade Agreement, which provides for the free flow of products - but not workers - between Mexico, Canada, and the United States, the EU includes workers as well as trade goods between its members. ${ }^{202}$ That is a wholly disruptive way of looking at immigration - at least between member nations.

\section{E. Public Oversight Disruption}

The examples of abusive or morally-questionable ICE enforcement strategies outlined in this essay demand oversight of the agency through an ethical lens-oversight grounded in a sense of morality, humanistic values, and human rights. While congressional committees may be charged with oversight of DHS, an independent public entity is needed that reviews and reports on the enforcement actions of ICE so that the agency's actions are regularly in plain view. The fact of congressional

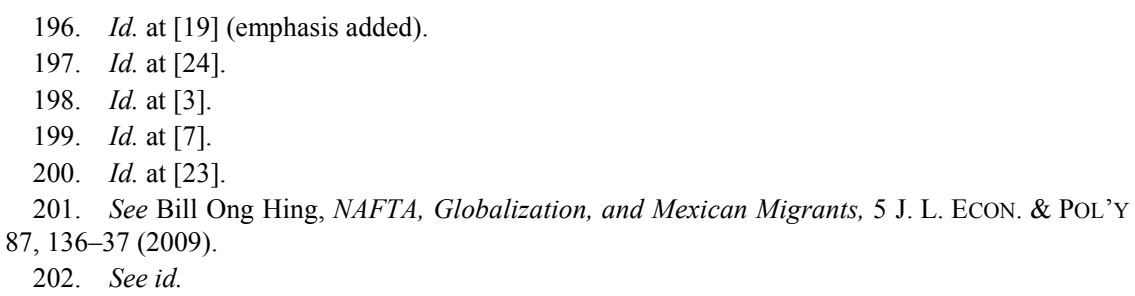


oversight or even an agency internal affairs department clearly is insufficient, given the ICE enforcement efforts that go unchecked except for successful litigation challenges in the most outrageous cases.

The history of civilian review boards of police departments is relevant to understanding why a similar public body is needed to regularly report on questionable immigration enforcement. Civilian review boards are composed of citizen representatives charged with the investigation of complaints by members of the public concerning police misconduct. ${ }^{203}$ The general goal of these boards is to enhance police accountability by ensuring that officers treat individuals without bias, use appropriate levels of force, operate free of corruption, and that procedures exist for the fair receipt and investigation of complaints against the police. ${ }^{204}$ Citizen involvement in the oversight of police is viewed as a valuable way to prevent misconduct.

The first interest in creating enforceable standards for police behavior emerged in the $1920 \mathrm{~s}^{205}$ This was an era focused on the police "professional" including the "creation of written policies on the use of force, arrest procedures, ... and the advent of Internal Affairs Departments (IADs)." ${ }^{06}$ Police reform during this time relied primarily on a strong police chief executive to implement change in a top-down method. ${ }^{207}$ One famous example of such a police chief was August Vollmer in Berkeley, California. ${ }^{208}$ His reforms in the police department were heralded as raising personnel standards and modernizing management. ${ }^{209}$ However, the problem with reform implemented by police chiefs is that it was a temporary solution; eventually that chief would leave the department and take with them the tools of change. ${ }^{210}$ Consequently, another method of regulating police behavior was needed.

In the 1920s and 1930s ideas begin to emerge about how police behavior could be regulated outside of the police department. Volunteer attorneys in the Los Angeles area during the 1920s proposed the idea of

\footnotetext{
203. William M. Wells \& Joseph A. Schafer, Civilian Complaint Review Boards, in ENCYCLOPEDIA OF LAW ENFORCEMENT 65, 65-68 (Larry E. Sullivan et al. eds., 2004).

204. Id.

205. Id.

206. John Chasnoff, A Review of Civilian Review, Synthesis/REgENERATIOn (2006), available at http://www.greens.org/s-r/39/39-10.html.

207. See Samuel Walker, Institutionalizing Police Accountability Reforms: The Problem of Making Police Reforms Endure, 32 St. LouIS U. PUB. L. REV. 57, 65 (2012).

208. See id.

209. Id.

210. Id. at 65-66.
} 
having private citizens evaluate complaints against police officers. ${ }^{211}$ Later, in 1931 the Wickersham Commission established by President Hoover recommended the creation of "some disinterested agency" in each city to assist people with their complaints. ${ }^{212}$

By the late 1940s, race riots and civil unrest spurred activists to push for civilian review boards. ${ }^{213}$ Continuing racial tensions in cities like New York, Detroit, Washington D.C., and Los Angeles finally spearheaded the creation of the first citizen oversight agency in this country. Formally instituted in 1948, the citizen review board for the Metropolitan Police in the District of Columbia was the first oversight agency developed in this country. ${ }^{214}$ It was comprised of three citizens who reviewed complaints referred by the police chief and offered suggestions on the proper disposition of each case. ${ }^{215}$ However, as was the case with many review boards, ${ }^{216}$ local politicians and law enforcement representatives worked against the board to hinder its effectiveness. Though the agency remained in existence until the mid1990s, lack of adequate funding and a large backlog of cases eventually led to its demise. ${ }^{217}$ Although reformers saw this as a setback, oversight agencies around the country continued to develop.

The Philadelphia American Civil Liberties Union (ACLU) called for the creation of a civilian review board in 1957 because of the strained relationship between the police and the black community. ${ }^{218}$ In 1958 , Philadelphia would produce the first significant oversight agency, called the Philadelphia Police Advisory Board. ${ }^{219}$ An executive order issued by Mayor Richardson Dillworth created the agency. ${ }^{220}$ The agency consisted of a board of citizens that would receive complaints, refer the complaints to the police department for investigation, and after reviewing the department's reports, make recommendations for action. ${ }^{221}$ Similar to what happened in Washington, this board suffered from a lack of

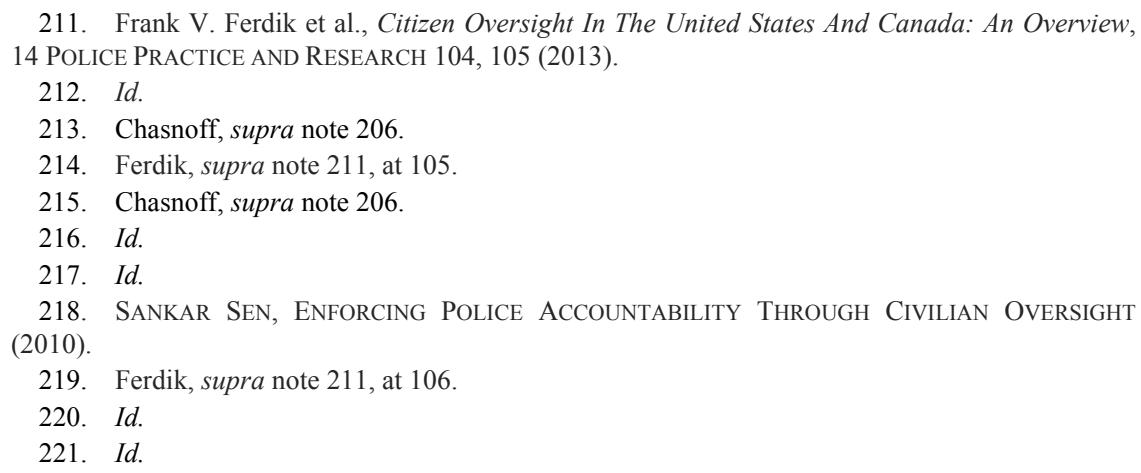


public and private support. ${ }^{222}$ This lack of support, combined with financial instability and an overwhelming number of cases collectively led to its closure in $1969 .^{223}$

Unfortunately, the backlash against citizen oversight by police unions, police officials, and police associations, including the International Association of Chiefs of Police (IACP), continued to limit the viability of citizen review boards. "Arguments against oversight included the belief that the police could discipline their own, that corruption was not as rampant as the media led the public to believe, and that oversight would undermine the police's autonomy and ability to effectively perform its job." ${ }^{224}$ For example, opponents of citizen oversight, most notably powerful police unions, were successful in their efforts to diminish any momentum on the part of oversight advocates in New York City, leading the New York City Civilian Complaint Review Board (NYCCRB) to suffer the same fate as the Washington and Philadelphia boards. ${ }^{225}$ Teamed with the Policeman's Benevolent Association, police unions staged a successful campaign in New York to convince voters to abolish the NYCCRB in $1966 .{ }^{226}$

However, civil rights tensions and progress in major cities in the United States during the late 1960s and early 1970s reversed this trend and reinstated a serious call for citizen accountability of the police. ${ }^{227}$ As public confidence and trust in government agencies waned, the desire for increased police accountability was refueled. ${ }^{228}$ For example, Kansas City established a citizen review system in 1969 that continues to survive today. ${ }^{229}$ Additionally, Chicago established the Office of Professional Standards (OPS) in 1974, a civilian staffed office that worked to expose police brutality and the misuse of force. ${ }^{230}$ This office continues to operate today in Chicago along with a Police Board consisting of nine civilian appointed members. ${ }^{231}$

The Chicago Police Board functions as an appellate body to which accused officers may seek final review. Police endorsement of these

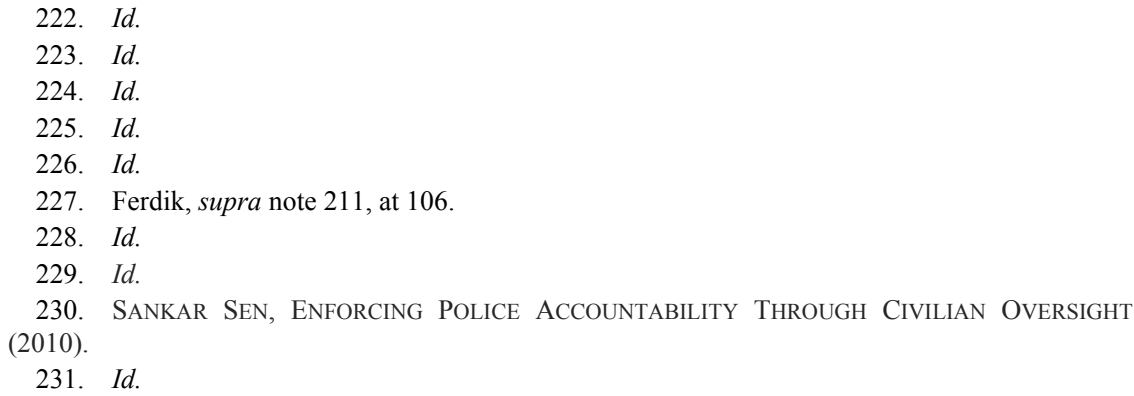


review system increased public support, leading to a renewed growth in this accountability mechanism across the country. ${ }^{232}$ In fact, cities such as Berkeley, Detroit and San Francisco have developed and maintained citizen oversight agencies since the 1970s and 1980s. ${ }^{233}$ In 1993, New York also reconstituted an all-civilian complaint review board (CCRB). ${ }^{234}$ The CCRB is now the largest civilian review board in the United States and presides over thousands of complaints annually. ${ }^{235}$ Today, 128 citizen oversight agencies operate across the country and have an important impact on the oversight of police misconduct and accountability. ${ }^{236}$

The ICE raids of Swift meatpacking plants in 2006 actually led to the establishment of a short-lived review body that is a good example of potential public review of immigration enforcement. ${ }^{237}$ After ICE swept up and detained thousands of workers from six meatpacking plants across the country during one of the nation's largest immigration raids, the United Food and Commercial Workers Union (UFCW) empaneled a group of former elected officials, labor leaders, academics, civil rights leaders and immigration and legal experts who spent more than a year holding regional hearings, interviewing witnesses and soliciting input from a wide range of workers, elected officials, policy experts, psychologists, and religious and community leaders. ${ }^{238}$ The commission then released a comprehensive report documenting the devastation and destruction that immigration raids had on families, workplaces, and communities across the country. ${ }^{239}$ The report, Raids on Workers: Destroying Our Rights, offered a critical analysis of one of the central components of the Bush Administration's immigration strategy and provided a detailed account of how heavy-handed enforcement tactics

\footnotetext{
232. Ferdik, supra note 211, at 106.

233. Id

234. Id.

235. Larry E. Sullivan, The SAGE Glossary of the Social and Behavioral Sciences (2009).

236. See Links to Oversight Agencies U.S., THE NAT'L ASS'N FOR CiviLIAN OverSight OF LAW ENFORCEMENT, http://www.nacole.org/nacole-resources/oversight-agencies/links-to-oversight-agenc ies-u-s/ (last visited May 25, 2015).

237. National Commission Investigating Misconduct by Immigration Enforcement Agents Holds Public Hearing in Des Moines, UFCW (Apr. 30, 2008), http://www.ufcw.org/2008/04/30/nationalcommission-investigating-misconduct-by-immigration-enforcement-agents-holds-public-hearing-indes-moines/.

238. See Raids on Workers: Destroying Our Rights: National Commission Condemns Workplace Immigration Raids, Report Finds Raids were Counterproductive, Unlawful and Ineffective, MiNORITY NEWS (Apr. 7, 2015), http://www.blackradionetwork.com/raids_on_workers_ destroying_our_rights.

239. Id.
} 
led to systemic abuse of workers' rights and a willful disregard for the rule of law. ${ }^{240}$

According to Joseph T. Hansen, founding chairman of the commission and president of the UFCW:

What we have uncovered is that during the Bush Administration ICE agents repeatedly trampled on innocent workers' constitutional rights. These were not isolated incidents, but systemic problems that occurred in almost every region of the country. No government agency is above the law, and no worker should have to face the mistreatment and misconduct that these hardworking men and women were subjected to under the Bush Administration. ${ }^{24}$

Upon its creation, the commissioners set out to achieve the following objectives: conduct hearings on allegations of ICE abuse and misconduct in locations across the country; hear from workers and their families on the impact of ICE raids; hear testimony from community leaders, academics, constitutional experts, and the business community; inform the public and elected officials; and issue a report on the findings with a plan of action to protect workers' constitutional rights from any future abuse. $^{242}$

At each hearing, clear patterns began to emerge regarding the tactics used by ICE agents and how the procedures used by these officials were compromising the rights of workers. The testimony the commission received revealed several disturbing patterns: U.S. citizens and legal permanent residents detained for hours unable to leave even after establishing their status; a lack of coordination by ICE with state and local labor and child welfare agencies; violations of the Fourth Amendment; the use of massive amounts of taxpayer resources and personnel to administer civil warrants; repeated incidents of racial profiling and harassment; the human toll of immigration enforcement, including family separation and children left without proper care; and lasting economic and psychological devastation of communities and families in the aftermath of workplace and community raids. ${ }^{243}$

Among its many recommendations, the UFCW report urged vigorous oversight of ICE's activities and the enhancement of legal protections against abuse. ${ }^{244}$ At least for a period of time, the report had some 
impact. As the Obama administration came into office, new DHS secretary Janet Napolitano announced that Bush-style ICE raids were not part of her enforcement strategy. ${ }^{245}$ However, as we have seen, several years later, ICE restarted strikingly-similar operations under the auspices of its targeted enforcement raids. ${ }^{246}$ And other Obama administration enforcement abuses such as Secure Communities were instituted. ${ }^{247}$ If the oversight recommended by the UFCW had been in place, these abuses may have been stopped or at least restrained.

\section{CONCLUSION}

Speaking before an audience at Washington State University several years ago, I was challenged by a member of the campus Republican student group who was upset at my criticism of the attempted prosecution of Shanti Sellz and David Strauss. Sellz and Strauss were college students who were volunteering with "No More Deaths," a human rights organization at the border that provided water and other sustenance to border crossers facing searing desert heat in the middle of the summer. They were arrested and charged with knowing transportation of undocumented immigrants within the United States after they drove two migrants who were dying of exposure to the hospital. ${ }^{248}$

"How can you defend the actions [of Sellz and Strauss]? They knew the crossers were illegal," demanded the young Republican. I asked him, "What would you have them do - allow the individuals they came across to simply die?" His answer was an emphatic "yes." Stunned, my reaction was esoteric-about how the U.S. Attorney should have exercised prosecutorial discretion not to prosecute and how the actions of Sellz and Strauss were acts of civil disobedience.

Back at my hotel later that evening, I thought back on the exchange. In retrospect, what I should have asked the young man was, "Really, let them die? Is that what your parents have taught you?" And since that time, I have realized, it is not just about whether his parents should have done better to help him develop a more humane moral compass. The

\footnotetext{
245. See Secretary Seeks Review of Immigration Raid, N.Y. TIMES (Feb. 26, 2009), http://www.nytimes.com/2009/02/26/washington/26immig.html.

246. See supra notes $35-37$ and accompanying text.

247. See supra notes $22-28$ and accompanying text.

248. E.J. Montini, Saving Immigrants from a Horrid Death is not a Crime-yet, AZCENTRAL.COM, (Sept. 17, 2006, 12:00 AM), http://www.azcentral.com/news/columns/articles/ 0917montini0917.html.
} 
task belongs to all of us. We have the duty to remind him and others that there is more to life and more to being a member of a global society than enforcing immigration laws that separate families in the name of maintaining borders.

Increased ICE raids, stepped up border enforcement, and employer sanctions have not reduced undocumented immigration to the United States. The failure of these harsh efforts must teach us something. The enforcement-only approach has resulted in human tragedy, increased poverty, and family separation, while undocumented workers continue to flow into the United States. This is a challenge that requires us to understand why workers come here and to address the challenge in a more sensible manner.

In the meantime, I encourage those who agree that our nation's methods of enforcing immigration laws is lacking a strong moral base, to engage in disruptive actions until our leaders come up with more innovative disruptions of that enforcement philosophy. Just as on-thestreet disruption has led to disruptive innovation, namely, the monumental executive action announcements by President Obama, we can push for more. Parents of DREAMers have been left out of these protections. Lawful permanent residents and refugees who have been labelled "aggravated felons" have been left out-even those who demonstrate clear progress toward rehabilitation. Immigration laws and procedures result in deportation decisions devoid of any sense of human rights values or proportionality.

Constant disruption is needed in all forms - protests, public oversight, immigrant engagement, litigation, and individual representation - if we are to convince public policy leaders to review immigration enforcement policies with a moral foundation. With that foundation, our leaders can begin to reinvent and disrupt the reigning U.S. approach to immigration enforcement. The rules can be changed and enforcement philosophy reframed. 